\title{
NGNP - Creating Validated TRL and TDRMs for Critical Systems, Subsystems, and Components
}

John W. Collins John M. Beck Emmanuel O. Opare Layne F. Pincock

September 2008

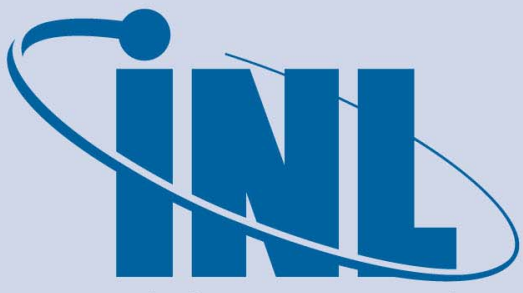

Idaho National Laboratory

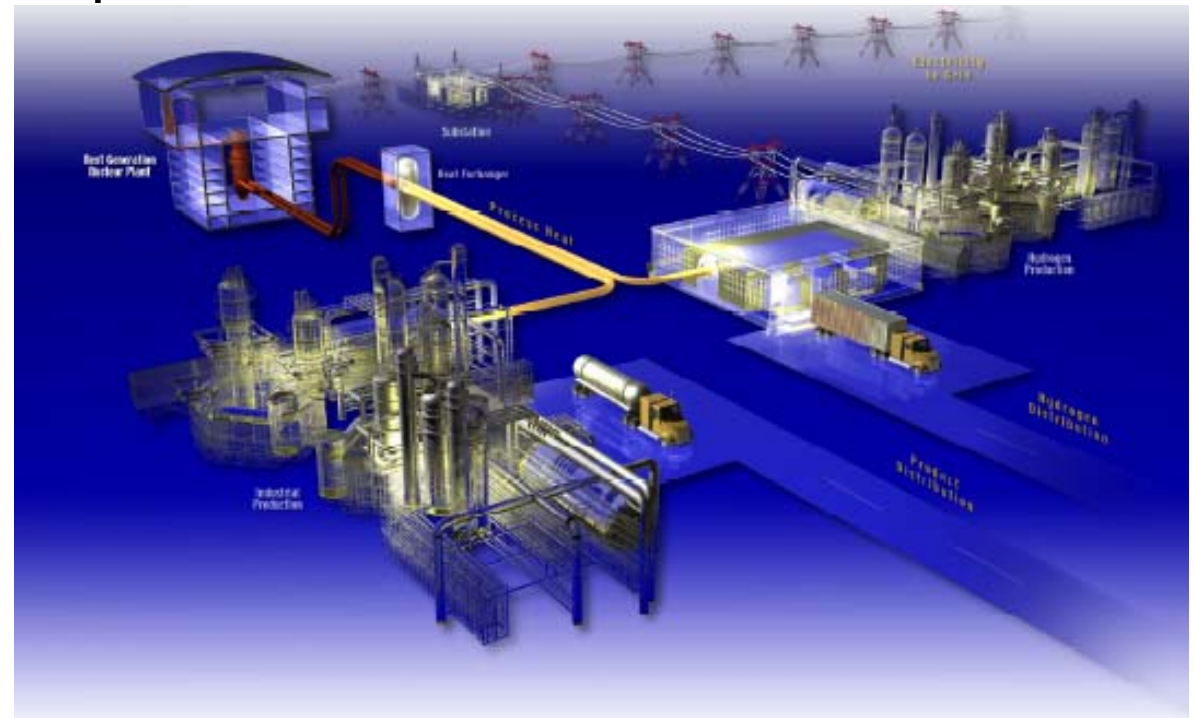

The INL is a U.S. Department of Energy National Laboratory operated by Battelle Energy Alliance 


\title{
NGNP - Creating Validated TRL and TDRMs for Critical Systems, Subsystems, and Components
}

\author{
John W. Collins \\ John M. Beck \\ Emmanuel O. Opare \\ Layne F. Pincock
}

September 2008

\author{
Idaho National Laboratory \\ Next Generation Nuclear Plant Project \\ Idaho Falls, Idaho 83415
}

http://www.inl.gov

Prepared for the

U.S. Department of Energy

Office of Nuclear Energy

Under DOE Idaho Operations Office

Contract DE-AC07-05ID14517 


\section{DISCLAIMER}

This information was prepared as an account of work sponsored by an agency of the U.S. Government. Neither the U.S. Government nor any agency thereof, nor any of their employees, makes any warranty, expressed or implied, or assumes any legal liability or responsibility for the accuracy, completeness, or usefulness, of any information, apparatus, product, or process disclosed, or represents that its use would not infringe privately owned rights. References herein to any specific commercial product, process, or service by trade name, trade mark, manufacturer, or otherwise, does not necessarily constitute or imply its endorsement, recommendation, or favoring by the U.S. Government or any agency thereof. The views and opinions of authors expressed herein do not necessarily state or reflect those of the U.S. Government or any agency thereof. 


\section{Next Generation Nuclear Plant Project}

\section{NGNP - Creating Validated TRL and TDRMs for Critical Systems, Subsystems, and Components}

INL/EXT-08-14842

September 2008

Approved by:

John W. Collins

Date

Lead Systems Engineer

Richard L. Garrett

Date

Engineering Director 


\section{EXECUTIVE SUMMARY}

This report describes the path forward in creating Technology Development Roadmaps (TDRMs) and their associated Technology Readiness Levels (TRLs) and Test Plans, introduces two draft Next Generation Nuclear Plant (NGNP) TDRMs, and documents the methods used to create them. The NGNP draft roadmaps for the hydrogen production system and the intermediate heat exchanger (IHX) are used as examples to depict the results of the TDRM process and the benefits of the TDRMs to the NGNP project. This report outlines a breakdown of the physical systems, subsystems, and components (SSCs) associated with each major area of NGNP for the purpose of assessing their individual technology maturity. Several options exist for which technologies are selected to fulfill the functions (i.e., heat production, heat transfer, heat-intensive applications) of the NGNP. These options are represented by differing SSCs and are grouped into reference designs, as currently proposed by the nuclear vendor community. Each SSC associated with each reference design is evaluated, rated, and assigned a technology readiness level (TRL). A rollup of the TRLs allows for comparison of the various reference designs.

A TDRM documents the tasks needed to obtain information in key discriminating criteria to support technology down selection, and the tasks and tests required to sufficiently mature the technology and enhance project performance. The TRL and TDRMs will be assessed and validated by an independent board of subject matter experts. The set of validated TDRMs along with their associated documentation will represent the path forward for the NGNP project to complete their mission to develop and demonstrate design, performance, operational, licensing, and economic viability of high-temperature gas reactor and leading process heat technologies. This report presents the path forward, methods, and tools used to understand the requirements, manage the uncertainty, and mitigate the risk early in the NGNP project. The key method, TDRMs, is the means to facilitate NGNP risk-informed decision making, technology down selection, and technology qualification and maturation while serving to coordinate engineering, research and development, and licensing efforts.

In summary, this process provides the following benefits to the NGNP project:

- Identifies precise project objectives and helps focus resources on critical technologies that are needed to meet those objectives

- Creates a consensus vision of NGNP project needs based on capabilities needed now and in the future

- Provides early identification of high-risk items and allows early focused attention to reduce later cost overruns and schedule delays.

- Supports engineering and R\&D priorities and schedule development, and assignment of resources. 


\section{CONTENTS}

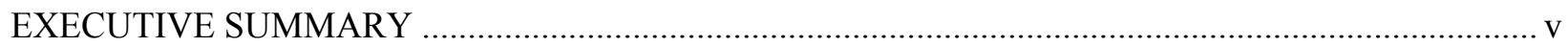

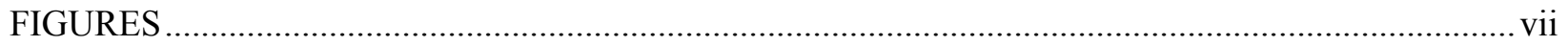

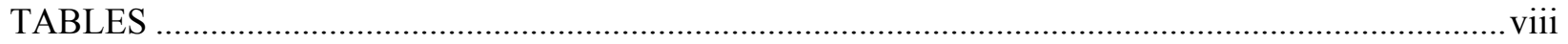

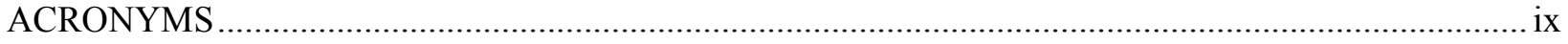

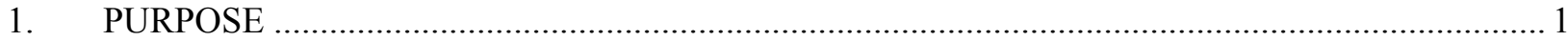

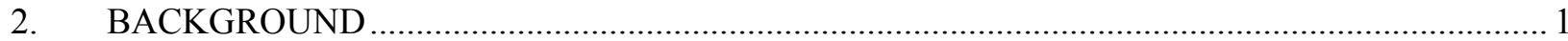

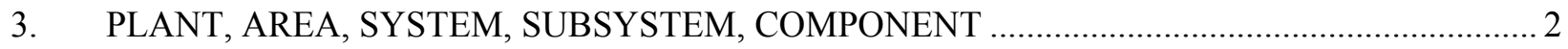

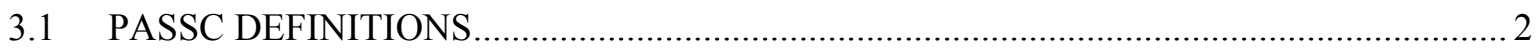

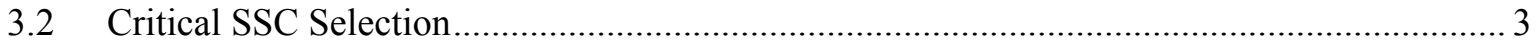

4. TECHNOLOGY READINESS LEVELS FOR EACH REFERENCE DESIGN .......................... 4

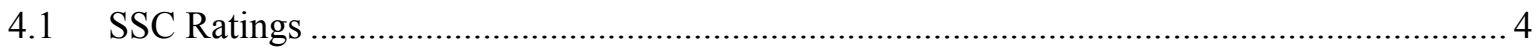

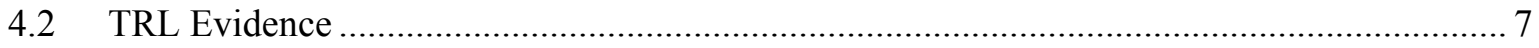

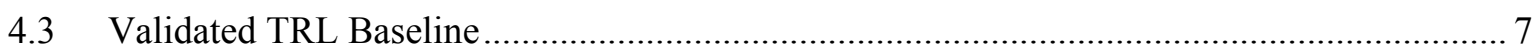

5. PATH FORWARD TO MATURE NEEDED TECHNOLOGY …............................................. 9

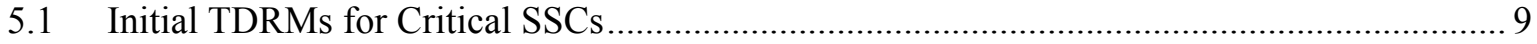

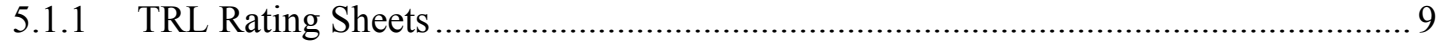

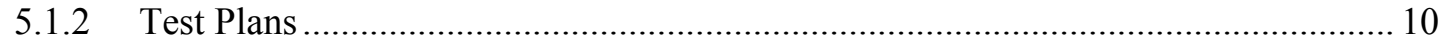

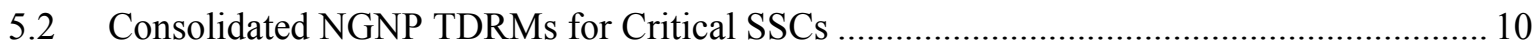

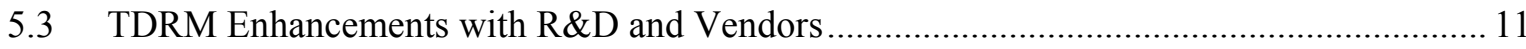

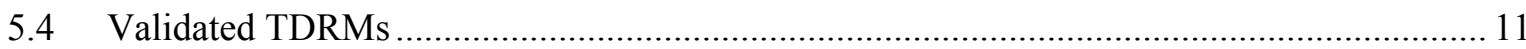

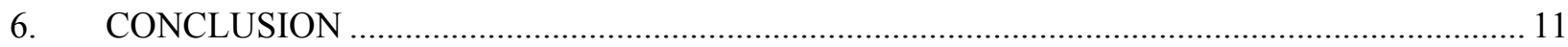

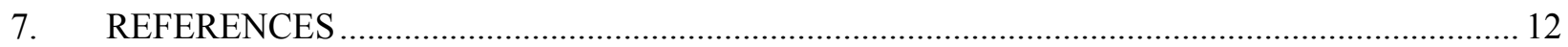

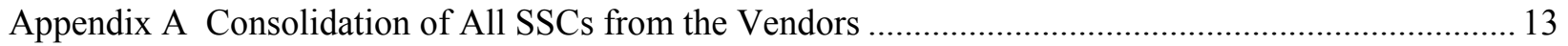

Appendix B Example NGNP Technology Development Roadmaps....................................................25

\section{FIGURES}

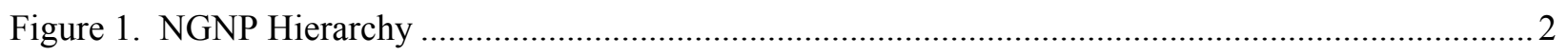

Figure 2. Technology Readiness Levels .......................................................................................

Figure 3. NGNP System, Subsystem and Component Rollup .............................................................5 


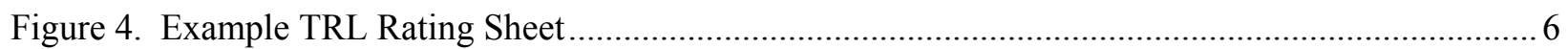

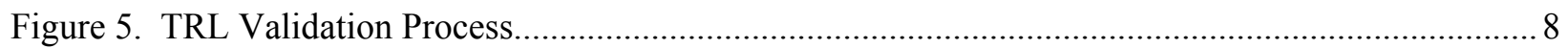

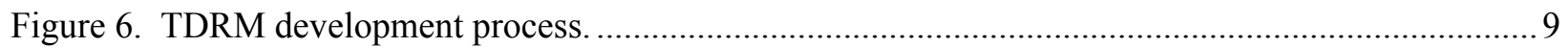

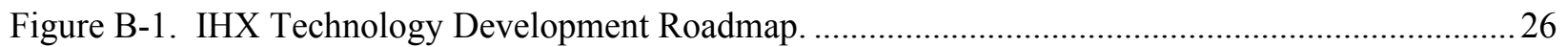

Figure B-2. HTE Hydrogen Production Technology Development Roadmap ........................................22

Figure B-3. Hybrid Sulfur Hydrogen Production Technology Development Roadmap..........................28

Figure B-4. Sulfur-Iodine Hydrogen Production Technology Development Roadmap ..........................29

\section{TABLES}

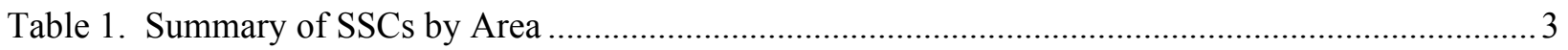

Table 2. Vendor-Identified Critical SSCs as of September 2008...................................................... 3 


\section{ACRONYMS}

\begin{tabular}{|c|c|}
\hline BOP & Balance of Plant \\
\hline $\mathrm{CCS}$ & Core Conditioning System \\
\hline DOD & U.S. Department of Defense \\
\hline GA & General Atomics \\
\hline HPS & Hydrogen Production System \\
\hline HTE & high-temperature electrolysis \\
\hline HTS & Heat Transfer System \\
\hline HVAC & Heat, Ventilation and Air Conditioning \\
\hline $\mathrm{I} \& \mathrm{C}$ & Instrumentation and Control \\
\hline IHX & intermediate heat exchanger \\
\hline IPS & Investment Protection System \\
\hline NASA & National Aeronautics and Space Administration \\
\hline NGNP & Next Generation Nuclear Plant \\
\hline NHSS & Nuclear Heat Supply System \\
\hline PACS & Priority Actuator Control System \\
\hline PASSC & Plant, Area, System, Subsystem, Component \\
\hline PAMS & Post Accident Monitoring System \\
\hline PCS & Power Conversion System \\
\hline PHTS & Primary Heat Transport Systems \\
\hline $\mathrm{R} \& \mathrm{D}$ & research and development \\
\hline RCCS & Reactor Cavity Control System \\
\hline RCLS & Reactor Control and Limitation System \\
\hline $\mathrm{RCS}$ & Reactivity Control System \\
\hline RPS & Reactor Protection System \\
\hline RPV & Reactor Pressure Vessel \\
\hline SeMS & Seismic Monitoring System \\
\hline SHTS & Secondary Heat Transport System \\
\hline SME & subject matter expert \\
\hline $\mathrm{SSC}$ & systems, subsystems, and components \\
\hline TDRM & Technology Development Roadmap \\
\hline TRL & Technology Readiness Level \\
\hline $\mathrm{V} \& \mathrm{~V}$ & Verification and Validation \\
\hline
\end{tabular}


This page intentionally left blank. 


\section{NGNP - Creating Validated TRLs and TDRMs for Critical Systems, Subsystems, and Components}

\section{PURPOSE}

This report describes the path forward in creating Technology Development Roadmaps (TDRMs) and their associated Technology Readiness Levels (TRLs) and Test Plans, introduces two draft Next Generation Nuclear Plant (NGNP) TDRMs, and documents the methods used to create them. The NGNP draft roadmaps for the hydrogen production system and the intermediate heat exchanger (IHX) are used as examples to depict the results of the TDRM process and the benefits of the TDRMs to the NGNP project.

\section{BACKGROUND}

The TRL rating process is an assessment tool, originating with NASA and U.S. Department of Defense (DOD) $)^{[1]}$, to evaluate the deployment readiness of a technology and its readiness to function in an integrated environment. The NGNP is using TRLs as the assessment tool with a tailored scale of 1 to 10 , compared to the standard 1 to 9 scale used by NASA and DOD. The additional rating allows the NGNP to assess readiness for full commercialization following the construction and successful operation of the NGNP.

Technology roadmaps for each NGNP System, Subsystem (Structure), and Component (SSC) are being developed to:

- Set the vision for and drive the needed actions to down select technologies and designs

- Ensure technology readiness is demonstrated through testing, modeling, piloting, and prototyping

- Develop the test plans required to provide demonstrable evidence of the technology maturation required for codification and qualification.

In the NGNP application, TDRMs provide the framework and structure required to systematically perform decision analysis, reduce risk, and mature technologies in a cost effective and timely manner. The process includes Structure Identification, Technology Readiness Assessment, Technology Selection, Technology Maturation, and Test Plan Development. 


\section{PLANT, AREA, SYSTEM, SUBSYSTEM, COMPONENT}

\subsection{PASSC DEFINITIONS}

The NGNP is comprised of five areas. The five NGNP areas are Nuclear Heat Supply, Heat Transport, Hydrogen Production, Power Conversion, and Balance of Plant. Each area is further broken down into systems, which are comprised of subsystems, which are further comprised of components. This breakdown, as shown in Figure 1, makes up the Plant, Area, System, Subsystem, and Component (PASSC) hierarchy for NGNP.

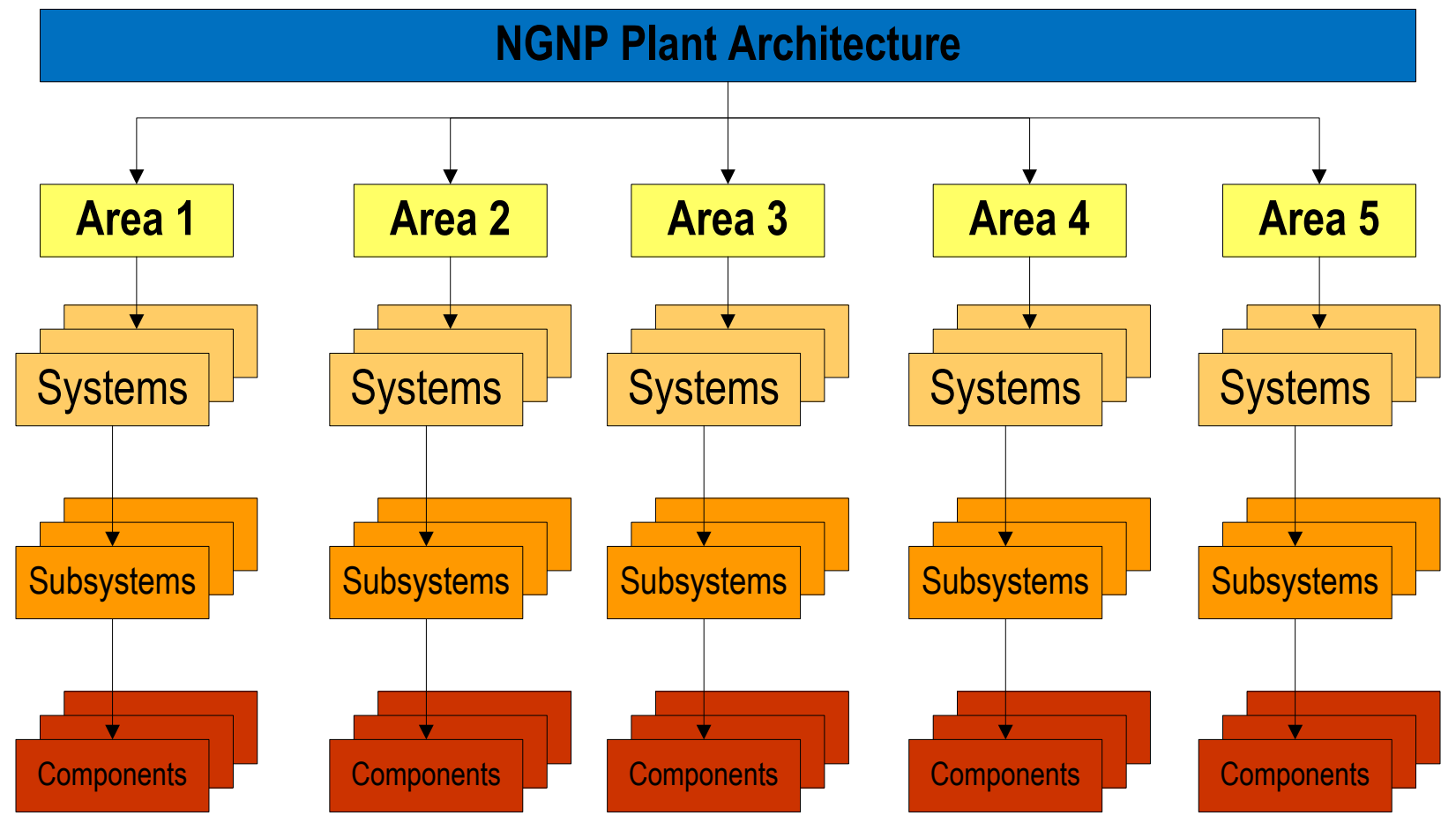

Figure 1. NGNP Hierarchy

Given the five areas for the NGNP, vendors were asked to identify their recommended SSCs for each area of the Plant. The vendors (i.e., Westinghouse, AREVA, and General Atomics [GA]) recommended $\mathrm{SSCs}$ required to perform the desired functions and meet the requirements specified by the project.

To document the vendors' recommended SSCs, systems engineers developed an overarching architecture of SSCs for each reference design. The architecture contains 410 SSCs, and it is anticipated that this number will continue to increase as the NGNP project progresses. Table 1 shows the total SSCs under each NGNP area; Appendix A contains a consolidation of all SSCs from the vendors. At this stage of development, all vendor-recommended SSCs and technologies have been included since technology down-selection has not yet occurred. 
Table 1. Summary of SSCs by Area

\begin{tabular}{|lc|cc|c|c|c|}
\hline $\begin{array}{l}\text { NGNP } \\
\text { Areas }\end{array}$ & $\begin{array}{l}\text { Nuclear } \\
\text { Heat Supply }\end{array}$ & $\begin{array}{l}\text { Heat } \\
\text { Transport }\end{array}$ & $\begin{array}{l}\text { Hydrogen } \\
\text { Production }\end{array}$ & $\begin{array}{l}\text { Power } \\
\text { Conversion }\end{array}$ & $\begin{array}{l}\text { Balance of } \\
\text { Plant }\end{array}$ & Total SSCs \\
\hline Systems & 16 & 3 & 5 & 11 & 22 & $\mathbf{5 7}$ \\
Subsystems & 76 & 16 & 11 & 40 & 25 & $\mathbf{1 6 8}$ \\
Components & 67 & 81 & 1 & 18 & 18 & $\mathbf{1 8 5}$ \\
\hline Total SSCs & 159 & 100 & 17 & 69 & 65 & $\mathbf{4 1 0}$ \\
\hline
\end{tabular}

\subsection{Critical SSC Selection}

Using their individual reference designs, the vendors selected critical SSCs to be evaluated for road mapping. Critical SSCs, at a minimum, are defined as those components that are not commercially available or do not have proven industry experience. Table 2 encompasses all critical SSCs for the NGNP as of September 2008 and may change along with future NGNP developments.

Table 2. Vendor-Identified Critical SSCs as of September 2008.

\begin{tabular}{|c|c|c|c|}
\hline \multicolumn{4}{|c|}{ Critical SSCs } \\
\hline $\begin{array}{l}\text { NGNP } \\
\text { Areas }\end{array}$ & Westinghouse Electric Company LLC & AREVA NP Inc. & General Atomics \\
\hline $\begin{array}{l}\text { Nuclear Heat } \\
\text { Supply }\end{array}$ & $\begin{array}{l}\text { Fuel Elements } \\
\text { Core Internal Structure (Graphite) } \\
\text { Core Internal Structure (Ceramics) } \\
\text { Reactor Cavity Cooling System (RCCS) } \\
\text { Core Conditioning System (CCS) } \\
\text { Reactivity Control System (RCS) } \\
\text { Reactor Shut Down Cooling System (RSS) } \\
\end{array}$ & $\begin{array}{l}\text { Vessel System } \\
\text { Reactor Vessel Internals } \\
\text { Neutron Control Equipment } \\
\text { Nuclear Instrumentation } \\
\text { Reactor Core }\end{array}$ & $\begin{array}{l}\text { Reactor Internals } \\
\text { Neutron Control System } \\
\text { Reactor Core (inc Graphite) } \\
\text { Reactor Pressure Vessel }\end{array}$ \\
\hline Heat Transport & $\begin{array}{l}\text { Intermediate Heat Exchanger (Metallic) A } \\
\text { Intermediate Heat Exchanger (Ceramic) A } \\
\text { Intermediate Heat Exchanger (Metallic) B } \\
\text { PHTS Helim Circulator } \\
\text { PHTS High Temperature Valves } \\
\text { SHTS Flow Coupling and Mixer Chamber } \\
\text { SHTS Circulator } \\
\text { SHTS Valve } \\
\text { Piping (secondary circuit from reactor to IHX and } \\
\text { between IHX vessels) } \\
\text { Piping (primary circuit from reactor to IHX and } \\
\text { between IHX vessels) }\end{array}$ & $\begin{array}{l}\text { Primary He Circulator } \\
\text { High Temperature Flapper Valve } \\
\text { Helical Tube Intermediate Heat } \\
\text { Exchanger } \\
\text { Primary Hot Duct } \\
\text { Secondary He Circulator } \\
\text { High Temperature Isolation Valve } \\
\text { Compact Plate IHX }\end{array}$ & $\begin{array}{l}\text { Helium Circulator } \\
\text { Intermediate Heat Exchanger } \\
\text { High Temperature Ducting \& } \\
\text { Insulation } \\
\text { Other Heat Exchangers } \\
\text { High Temperature Valves }\end{array}$ \\
\hline $\begin{array}{l}\text { Hydrogen } \\
\text { Production }\end{array}$ & Hydrogen Production System & Hydrogen Production System & Hydrogen Production System \\
\hline $\begin{array}{l}\text { Power } \\
\text { Conversion }\end{array}$ & Steam Generator & Steam Generator & $\begin{array}{l}\text { Steam Generator } \\
\text { PCS Rankine Cycle }\end{array}$ \\
\hline $\begin{array}{l}\text { Balance of } \\
\text { Plant }\end{array}$ & NA & $\begin{array}{l}\text { Startup and Decay Heat Removal } \\
\text { Primary Loop Instrumentation } \\
\text { (Bounding Case) } \\
\text { Reactor Cavity Cooling System } \\
\text { Fuel Handling System }\end{array}$ & $\begin{array}{l}\text { Fuel Handling \& Storage } \\
\text { Instrumentation and Control }\end{array}$ \\
\hline
\end{tabular}




\section{TECHNOLOGY READINESS LEVELS FOR EACH REFERENCE DESIGN}

This section of the report summarizes the use of TRLs within the NGNP Project. The TRL process is a systems engineering tool used to assess the maturity of technologies and to assist in decision-making. The NGNP Technology Readiness Levels Plan (September 2008) ${ }^{[2]}$ addresses the approach of how TRLs are scaled and integrated for the PASSC structure used for the NGNP project.

The TRLs are associated with the entire NGNP or the applicable PASSC and are an input to inform NGNP project decision makers of the readiness of a particular technology or component. For TRLs 1-5, assessment typically occurs on an individual technology or component with a calculated roll up TRL for the associated islands, systems, and subsystems. During TRLs 5-10, integrated testing occurs, allowing for TRL assessments directly against subsystems and systems. TRLs are shown in Figure 2.

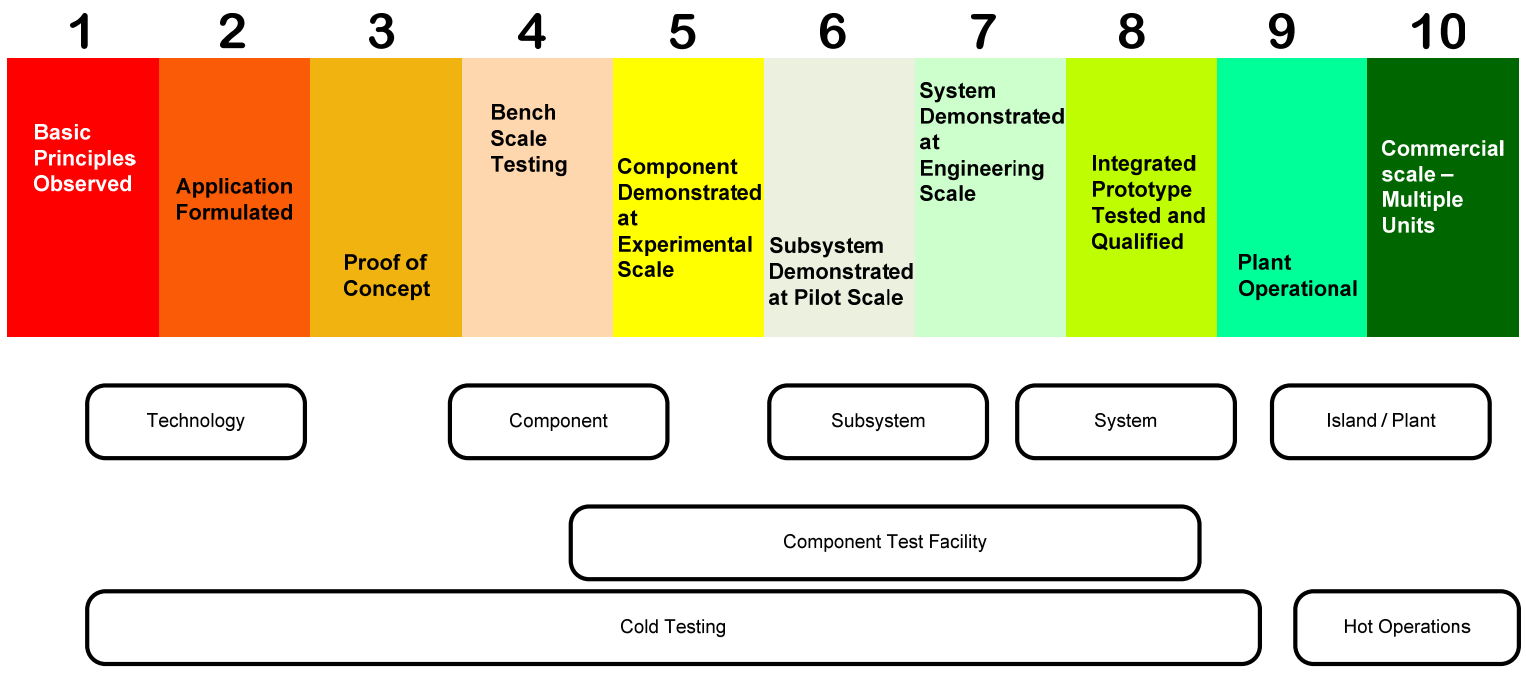

Figure 2. Technology Readiness Levels

The three vendors are assigned to provide TRL ratings for all of the SSCs associated with their reference design. The reference design is associated with the Preconceptual Design Reports ${ }^{[2,4,5]}$ presented as the basis of the NGNP.

\subsection{SSC Ratings}

Each vendor is submitting their critical SSCs with a TRL score or rating according to the definitions provided to them.

An example of how a vendor will rate an SSC is as follows:

- Determine and identify an SSC that is critical to NGNP

- Evaluate the maturity of the SSC

- Assign a TRL rating according to definition provided

- Provide evidence to justify the TRL rating. 
TRL ratings will be rolled up according to the level of SSC it is associated with. The three methods for roll up, minimum, maximum, and average are shown in Figure 3. In the "Min TRL" method, the subsystem will be assigned the TRL rating of the lowest component. Likewise, a system will be assigned the TRL rating of the lowest subsystem. The other two alternatives are the "Avg TRL" rating and the "Max TRL" rating. The former represents the mathematical average of TRLs for an Area, with roll up averages from subsystems and components. The latter is presented to show the highest TRL rating give for any of the SSCs within an Area. Currently only the minimum TRL rating is deployed. In this method, a system or subsystem will never receive a rating higher than its lowest subsystem or component rating.

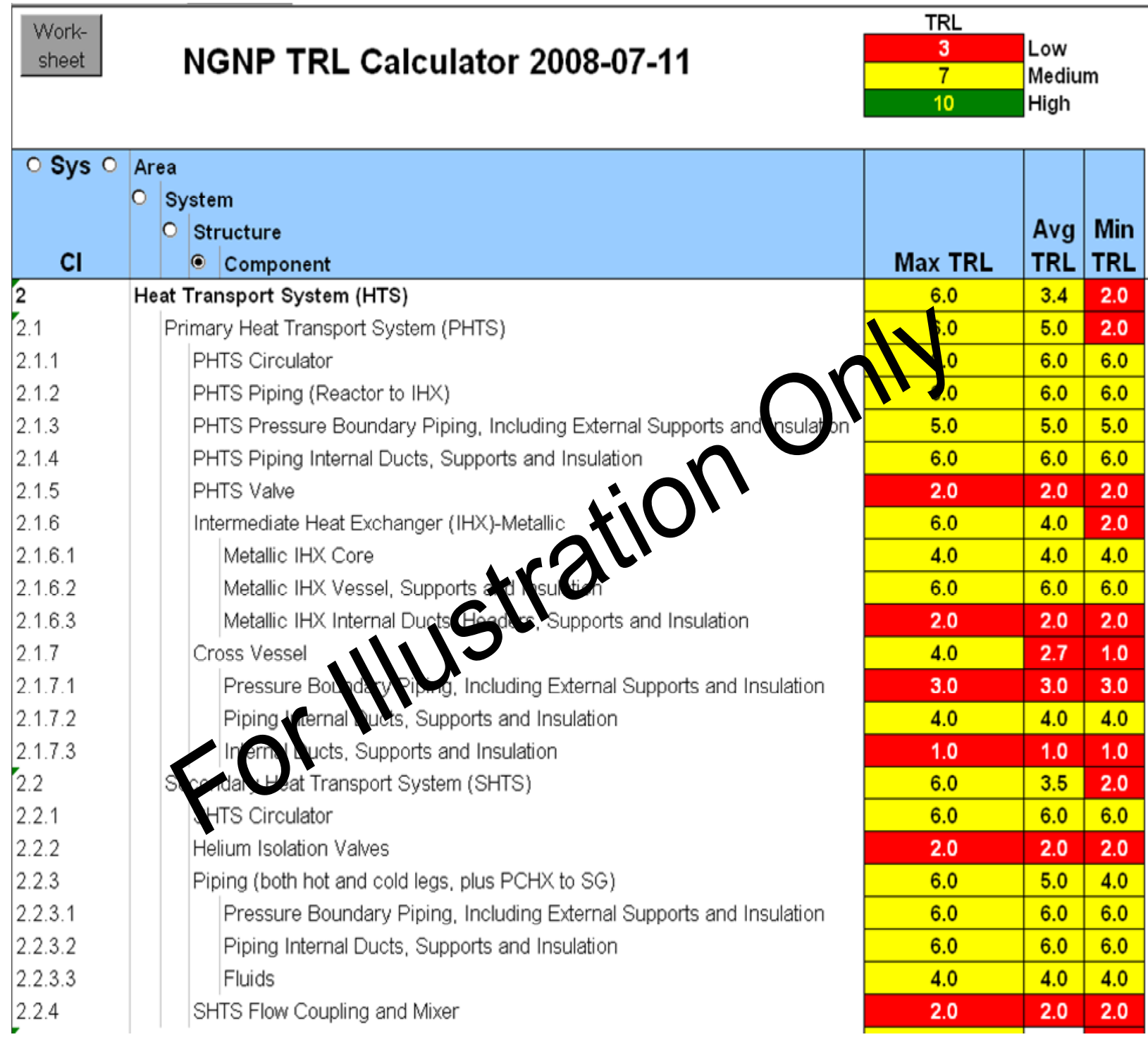

Figure 3. NGNP System, Subsystem and Component Rollup

TRL rating sheets document and justify the current state of readiness (see Figure 4). Actions needed to achieve the next level of readiness are also documented, along with anticipated cost, schedule, and design data needing to be resolved. 


\begin{tabular}{|c|c|c|c|}
\hline \multicolumn{4}{|c|}{ TRL Rating Sheet } \\
\hline Vendor Name: & Document Number: & \multicolumn{2}{|c|}{ Revision: } \\
\hline$\square$ System & $\square$ Subsystem/Structure & \multicolumn{2}{|c|}{$\square$ Technology } \\
\hline \multicolumn{4}{|c|}{ Title: Intermediate Heat Exchanger (IHX A - Metallic) $\left(950^{\circ} \mathrm{C}\right)$} \\
\hline \multicolumn{4}{|c|}{$\begin{array}{l}\text { Description: } \\
\text { The Technology Readiness Level for a metallic intermediate heat exchanger operating in the } \\
\text { NGNP at } 950^{\circ} \mathrm{C} \text { for up to } 10 \text { years has been assessed as TRL } 2 \text { based on studies noted below. } \\
\text { The actions required to go to a level of TRL } 3 \text { are also shown below. }\end{array}$} \\
\hline$\square$ NHSS & $\square$ HPS & \multicolumn{2}{|c|}{$\square \mathrm{BOP}$} \\
\hline ISSCTBS: & Parent: & \multicolumn{2}{|l|}{ WBS: } \\
\hline \multicolumn{4}{|c|}{ Technology Readiness Level } \\
\hline & \begin{tabular}{|l|} 
Next Lower \\
Rating Level \\
\end{tabular} & $\begin{array}{c}\text { Calculated } \\
\text { Rating }\end{array}$ & $\begin{array}{l}\text { Next Higher } \\
\text { Rating Level }\end{array}$ \\
\hline Generic Definitions (abbreviated & $\begin{array}{l}\text { Basic principles } \\
\text { observed }\end{array}$ & $\begin{array}{l}\text { Application } \\
\text { formulated }\end{array}$ & Proof of concept \\
\hline TRL & \begin{tabular}{r|r|} 
& 1 \\
\end{tabular} & 2 & 3 \\
\hline \multicolumn{4}{|c|}{ Basis for Rating (Attach additional sheets as needed) } \\
\hline \multicolumn{4}{|c|}{$\begin{array}{l}\text { - Special Study 20.3: High-Temperature Process Heat Transfer and Transport, NGNP-20-RPT, Rev } \\
\text { 0, January } 2007 \\
\text { - PCDR Section 6: Heat Transport Systems, NGNP-06-RPT, Rev 0, April } 2007 \\
\text { - NGNP Conceptual Design Study: IHX and Heat Transport System, NGNP-HTS-RPT, Rev 0, } \\
\text { April } 2008\end{array}$} \\
\hline \multicolumn{4}{|c|}{$\begin{array}{l}\text { The recommendation resulting from these studies was a compact heat exchanger design (PCHE or plate- } \\
\text { fin) using Alloy } 617 \text { as the material for the heat exchanger core. }\end{array}$} \\
\hline \multicolumn{4}{|c|}{ Outline of a plan to get from current level to next level (Attach additional sheets as needed) } \\
\hline \multicolumn{2}{|c|}{ Actions (list all) } & Schedule & Cost $(\mathrm{K} \$)$ \\
\hline \multicolumn{2}{|c|}{$\begin{array}{l}\text { - } \text { Establish reference specification for Alloy } 617 \\
\text { - } \text { Procure reference heats of Alloy 617 } \\
\text { - } \text { Develop and assess effects of joining processes } \\
\text { - } \frac{\text { Determine or confirm thermal/physical and }}{\text { mechanical properties of Alloy 617 }} \\
\text { - } \frac{\text { Confirm effects of thermal aging and }}{\text { environmental exposure on Alloy 617 properties }} \\
\text { - } \text { Assess effects of grain size and section thickness } \\
\text { - Determine corrosion allowances for Alloy } 617\end{array}$} & & \\
\hline \multicolumn{2}{|c|}{$\begin{array}{l}\text { DDN(s) supported: HTS-01-01. HTS-01-02. HTS-01-03. } \\
\text { HTS-01-04. HTS-01-06, HTS-01-20, HTS-01-21. HTS- } \\
01-30\end{array}$} & \multicolumn{2}{|c|}{ Technology Case File: } \\
\hline \multicolumn{4}{|c|}{ Subject Matter Expert Making Determination: } \\
\hline Date: & \multicolumn{3}{|l|}{ Originating Organization: } \\
\hline
\end{tabular}

Figure 4. Example TRL Rating Sheet 
The set of TRL ratings is specific to the vendor reference design at a given set of operating conditions and associated requirements. For example, the initial TRL ratings provided by the vendors are against the requirements associated with a reactor outlet temperature of $950^{\circ} \mathrm{C}$ and 7 to $9 \mathrm{MPa}$ pressure. Due to the lack of codified material at these conditions, this set of TRL ratings is lower than the TRL ratings at an operating temperature and pressure of $800^{\circ} \mathrm{C}$ and $5 \mathrm{MPa}$. Hence, a requirement set will accompany each set of TRL ratings.

\subsection{TRL Evidence}

Each vendor will use a TRL calculator, a tool developed to assist vendors in assigning TRL ratings, to populate the associated TRL rating sheet. The rating sheets contain the evidentiary data to justify the TRL rating being assigned by the vendor.

Evidence can include previous experiments documented in journal reports or previous industrial applications; or other verifiable sources, such as documented work performed at national laboratories, industry laboratories, or university laboratories. All of the evidence, including the associated TRL rating, will be verified for completeness. The verification is to be performed by NGNP team members and will determine if the evidence is adequate for justifying the TRL rating.

\subsection{Validated TRL Baseline}

Through a structured and proven approach, each of the TRLs applied to critical SSCs will be validated. The TRL validation process defines an independent board of SMEs that will review each of the TRL rating, the TRL rating sheets, and TRL evidence received for each critical SSC identified by the vendors.

The completed TRL rating sheets will be verified and validated (V\&V) by an independent review board. The purpose of the V\&V Board is to provide the NGNP project with validated TRLs that will:

- Provide a common basis to compare the relative maturity of technologies

- Establish the baseline set of the critical SSCs that require TRL assessment

- Establish the current state of proposed technologies that are used as the starting point for TRLs

- Provide a consistent measure of readiness levels and confidence in the levels as inputs to quantifying performance, cost, and schedule risks.

The independent review board will assemble and review each of the vendors' critical SSCs. The board will use their expertise and knowledge to determine validity of the evidence. Figure 5 shows the TRL validation process. 


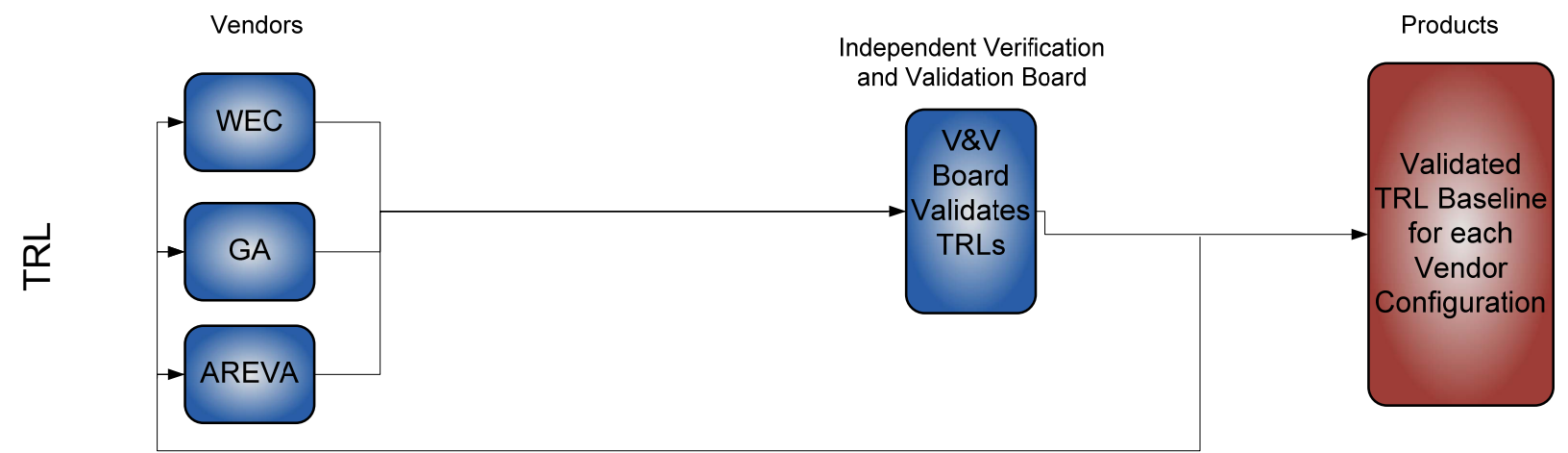

Figure 5. TRL Validation Process

After the review of evidence and the TRL ratings, the board will accept or reject the TRL ratings. Accepted TRL ratings become the validated TRL baseline for that reference design. 


\section{PATH FORWARD TO MATURE NEEDED TECHNOLOGY}

Once the validated TRL baseline is developed, a path forward for maturing these technologies and advancing the TRLs is needed. This path forward is defined by the roadmapping process. The TDRM focuses the research and development (R\&D) efforts and engineering studies on the known risks to advancing the technology. The roadmapping process provides the following benefits to the NGNP project:

- Identifies precise project objectives and helps focus resources on critical technologies that are needed to meet those objectives

- Creates a consensus vision of R\&D needs based on capabilities needed now and in the future

- Communicates capability-based technical needs among product/user organizations and the R\&D community

- Provides early identification of high-risk items and allows early focused attention to define appropriate risk mitigation.

- Supports engineering and R\&D priorities and schedule development, and assignment of resources.

The roadmaps drive the needed actions to down-select technologies and designs; demonstrate technologies and design readiness through testing, modeling, piloting, and prototyping; and develop the test plans required to demonstrate and provide evidence of technology maturation.

\subsection{Initial TDRMs for Critical SSCs}

The individual vendors are currently providing the NGNP project with TDRMs for each of the critical SSCs, as shown on the left of Figure 6. The total number of TDRMs that the individual vendors are planning on submitting is also shown.

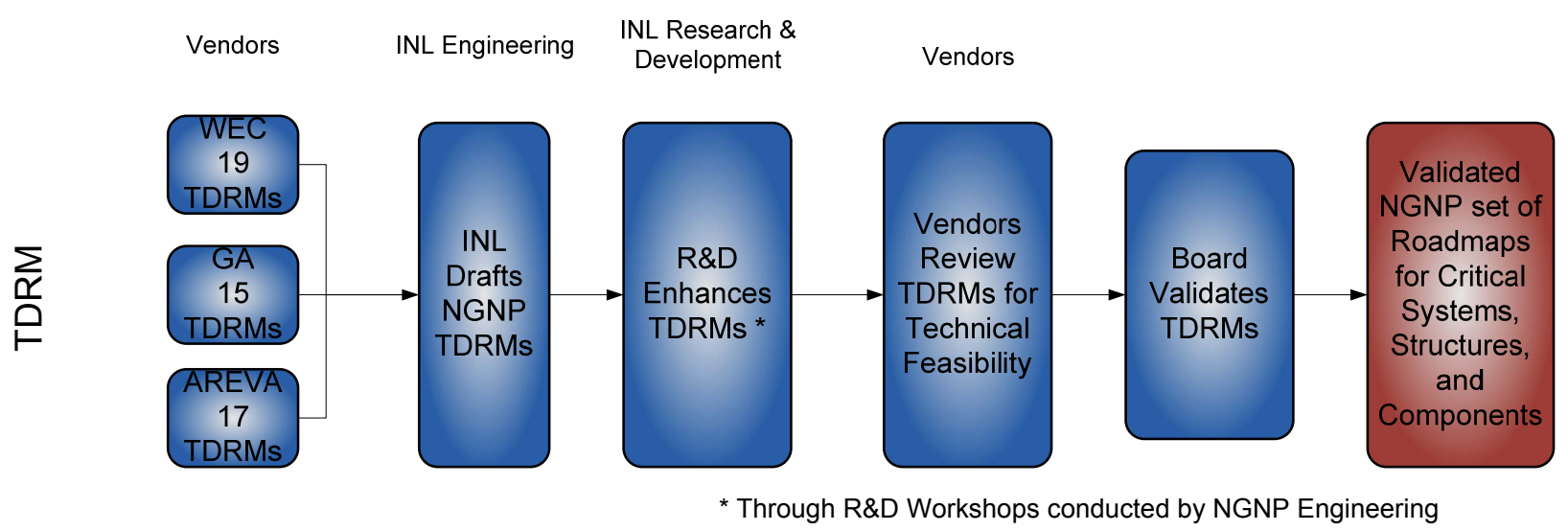

Figure 6. TDRM development process.

\subsubsection{TRL Rating Sheets}

The TRL rating sheets, as described in Section 4, are a part of the TDRM documentation package. 


\subsubsection{Test Plans}

Conceptual level test plans are being written for all the NGNP critical SSCs to advance the technology from its current level of readiness to a level required to support conceptual, preliminary, and final design. These test plans are SSC-specific and identify the current SSC TRLs and all research, modeling, and scaled testing required to achieve a TRL of 8 . The following information is included in the test plans:

- Test objective

- Test description

- Test conditions

- Test configuration/set-up

- Test duration

- Proposed test location

- Measured parameters

- Data requirements

- Test evaluation criteria

- Test deliverables

- Cost, schedule, and risk.

\subsection{Consolidated NGNP TDRMs for Critical SSCs}

NGNP will review and comment on the TDRMs as they are received from each of the vendors to help improve the quality and content of each TDRM. NGNP will consolidate the TDRMs for the critical SSCs (as shown in Figure 6). Two of these NGNP TDRMs are nearing completion and are included in draft form in Appendix B.

Figure B-1 shows the draft TDRM for the IHX. The TDRM for the hydrogen production system consists of three separate graphics, one for each of the candidate technologies. Figure B-2 shows the roadmap for High Temperature Electrolysis (HTE); Figure B-3 shows the roadmap for the Hybrid Sulfur process, and Figure B-4 shows the roadmap for the Sulfur-Iodine process.

Each of the roadmaps has the following features:

- The candidate technologies are shown on the left of the graphic. If shown, the down select process is also displayed on the left with the discriminating criteria and decision points.

- The center of the roadmap shows the tasks necessary to mature the technology toward commercial use.

- The tasks shown in dark blue are performance tests, which will have corresponding test plans.

- The lower portion of the roadmap shows the progression through the TRLs.

- Below each TRL marker is a list of performance criteria that have to be met to achieve the specified TRL.

- The tasks and TRLs are laid out according to the time line at the top of the roadmap. 
- Near the top of the roadmap, risk reduction can be shown as a series of shaded red bars with text explaining the risk, which is mitigated over time.

\subsection{TDRM Enhancements with R\&D and Vendors}

As the NGNP TDRMs are completed, they will undergo review by NGNP R\&D and each of the vendors for technical feasibility, as shown in Figure 5. This process will further improve the quality and content of the TDRMs and prepare them for validation.

\subsection{Validated TDRMs}

The completed NGNP TDRMs will be verified and validated by an independent review board. The purpose of the V\&V Board is to provide the NGNP project with validated TDRMs that will:

- Set the vision for and drive the needed actions to down-select technologies and designs

- Support risk-based decision making

- Establish the baseline set of the critical SSCs that require technology development

- Reduce the risk early in the project and thereby minimize cost overruns and schedule delays

- Identify risk-reducing tasks that can be accomplished early to support risk-informed decision making and technology down-selection.

- Alleviate the need for large-scale testing at each readiness level by identifying alternatives to physical testing, where appropriate

- Establish a uniform set of actions needed to achieve increases in technology readiness, which will be used to guide preparation of the NGNP TDRM

- Provide a consistent measure of readiness levels and confidence in the levels as inputs to quantifying performance, cost, and schedule risks.

\section{CONCLUSION}

The set of validated TDRMs along with their associated documentation will represent the path forward for the NGNP project to complete their mission to develop and demonstrate design, performance, operational, licensing, and economic viability of high-temperature gas reactor and leading process heat technologies. 


\section{REFERENCES}

1. Department of Defense Technology Readiness Assessment (TRA) Deskbook. Deputy Under Secretary of Defense for Science and Technology. May 2005

2. NGNP Technology Readiness Levels Plan. INL/MIS-08-14873. Idaho National Laboratory - NGNP Project. September 01, 2008.

3. NGNP and Hydrogen Production Preconceptual Design Report: Executive Summary Report. Document No. NGNP-ESR-RPT-001, Revision 0. Westinghouse Electric Company, LLC. May 2007.

4. NGNP with Hydrogen Preconceptual Design Studies Report: Executive Summary. Document No. 129052076-000. AREVA NP, Inc. June 2007.

5. Preconceptual Engineering Services for the Next Generation Nuclear Plant (NGNP) with Hydrogen Production: Executive Summary Report - NGNP and Hydrogen Production Preconceptual Design Studies Report. Document No. PC-000544, Revision 0. General Atomics. July 10, 2007. 


\section{Appendix A}

\section{Consolidation of All SSCs from the Vendors}


Appendix A

Consolidation of All SSCs from the Vendors

\begin{tabular}{|c|c|}
\hline Hierarchy & NGNP TRL MASTER COPY \\
\hline 1 & Nuclear Heat Supplv Svstem (NHSS) \\
\hline \multirow{2}{*}{1.1} & Reactor Unit System \\
\hline & Reactor Pressure Vessel (RPV) \\
\hline 1.1.1.1. & RPV - Upper Plenum Shroud Structure \\
\hline 1.1.1.2 & RPV - Main Vessel \\
\hline \multirow{2}{*}{$\begin{array}{l}1.1 .1 .3 \\
1.114\end{array}$} & RPV - Fasteners \\
\hline & Inlet/Outlet Flanges \\
\hline 1.1 .1 .5 & Fueling Interface-Cap \\
\hline \multirow{2}{*}{$\begin{array}{l}1.1 .1 .6 \\
1.17\end{array}$} & RPV - Internal Instrument Interface \\
\hline & RPV - Lower Plenum \\
\hline $\begin{array}{l}1.1 .1 .2 \\
1.1 .2\end{array}$ & Reactivity Control System (RCS) \\
\hline 1.1 .2 .1 & RCS - Control Rods \\
\hline & RCS - Control Rods Plenum \\
\hline & RCS - Control Interconnect \\
\hline & RPV- Neutron Control SubSystem \\
\hline & Outer and Inner Neutron Control Assemblies \\
\hline 1.1 .3 .2 & Neutron Source Range Detector Assemblies \\
\hline & RPV- Neutron Control Assembly \\
\hline & Nuclear Instrumentation (For Reactor Control) \\
\hline 1.1 .4 & Reactor Vessel Internals \\
\hline \multirow{2}{*}{$\begin{array}{l}1.1 .4 .1 \\
1.1 .4 .2\end{array}$} & Core Barrel Assembly \\
\hline & Upper Closure Head \\
\hline 1.1 .4 .3 & Bottom Head \\
\hline & Upper Core Restraint \\
\hline & Permanent Side Reflectors \\
\hline 1.1 .4 .6 & Metallic Core Support \\
\hline \multirow{2}{*}{$\begin{array}{l}1.1 .4 .7 \\
1.1 .4 .8\end{array}$} & Permanent Bottom Reflectors \\
\hline & Lower Floor Blocks \\
\hline 1.1.4.9 & Main Vessel \\
\hline \multirow{2}{*}{$\begin{array}{l}1.1 .4 .10 \\
1.1 .4 .11\end{array}$} & Sealing Device \\
\hline & Graphite Core Support Structure \\
\hline \multirow{2}{*}{$\begin{array}{l}1.1 .4 .12 \\
1.1 .5\end{array}$} & Top Plenum Shroud Structure \\
\hline & $\begin{array}{l}\text { Core Internal Structure (metallic, graphite, } \\
\text { ceramic) }\end{array}$ \\
\hline \multirow{2}{*}{$\begin{array}{l}1.1 .6 \\
1.1 .6 .1\end{array}$} & Fuel Elements (spheres) \\
\hline & Pebble (Graphite Matrix) \\
\hline \multirow{2}{*}{$\begin{array}{l}1.1 .6 .2 \\
1.1 .7\end{array}$} & Fuel Particles \\
\hline & IHX Pressure Vessel \\
\hline 1.1 .7 .1 & Main Vessel \\
\hline
\end{tabular}

\begin{tabular}{|c|c|}
\hline Hierarchy & WESTINGHOUSE TRL SSCs 1 \\
\hline 1 & Nuclear Heat Supply System (NHSS) \\
\hline 1.1 & Reactor Unit System \\
\hline & Reactor Pressure Vessel (RPV) \\
\hline & RPV - Upper Plenum Shroud Structure \\
\hline & RPV - Main Vessel \\
\hline & RPV - Fasteners \\
\hline \multirow{2}{*}{$\begin{array}{l}1.1 .1 .4 \\
1.1 .1 .5\end{array}$} & Inlet/Outlet Flanges \\
\hline & Fueling Interface-Cap \\
\hline 1.1 .1 .6 & RPV - Internal Instrument Interface \\
\hline \multirow{2}{*}{$\begin{array}{l}1.1 .1 .7 \\
1.1 .2\end{array}$} & RPV - Lower Plenum \\
\hline & Reactivity Control System (RCS) \\
\hline 1.1.2.1 & RCS - Control Rods \\
\hline \multirow{3}{*}{$\begin{array}{l}1.1 .2 .2 \\
1.1 .2 .3 \\
1.1 .3\end{array}$} & RCS - Control Rods Plenum \\
\hline & RCS - Control Interconnect \\
\hline & \\
\hline \multicolumn{2}{|l|}{ 1.1.3.1 } \\
\hline \multicolumn{2}{|l|}{ 1.1.3.2 } \\
\hline \multicolumn{2}{|l|}{1.1 .3 .3} \\
\hline \multicolumn{2}{|l|}{ 1.1.3.4 } \\
\hline \multicolumn{2}{|l|}{1.1 .4} \\
\hline \multicolumn{2}{|r|}{ Core Barrel Assembly } \\
\hline \multicolumn{2}{|l|}{ 1.1.4.2 } \\
\hline \multicolumn{2}{|l|}{ 1.1.4.3 } \\
\hline \multicolumn{2}{|l|}{ 1.1.4.4 } \\
\hline \multicolumn{2}{|l|}{ 1.1.4. } \\
\hline \multicolumn{2}{|l|}{ 1.1.4.6 } \\
\hline \multicolumn{2}{|l|}{ 1.1.4.7 } \\
\hline \multicolumn{2}{|l|}{ 1.1.4.8 } \\
\hline \multicolumn{2}{|l|}{ 1.1.4.9 } \\
\hline \multicolumn{2}{|l|}{ 1.1.4.10 } \\
\hline \multicolumn{2}{|l|}{ 1.1.4.11 } \\
\hline \multicolumn{2}{|l|}{1.1 .4 .12} \\
\hline 1.1.5 & Core Internal Structure (graphite, ceramic) \\
\hline 1.1 .6 & Fuel Elements (spheres) \\
\hline \multirow{2}{*}{$\begin{array}{l}1.1 .6 .1 \\
\text { 1.1.6. }\end{array}$} & Pebble (Graphite Matrix) \\
\hline & Fuel Particles \\
\hline 1.1 .7 & \\
\hline
\end{tabular}

\begin{tabular}{|c|c|}
\hline Hierarchy & AREVA PREFERRED TRL SSCs 1 \\
\hline 1 & Nuclear Heat Supply System (NHSS) \\
\hline \multirow{3}{*}{$\begin{array}{l}1.1 \\
1.1 .1 \\
1.1 .1 .1\end{array}$} & Reactor Unit System \\
\hline & Reactor Pressure Vessel (RPV) \\
\hline & \\
\hline \\
\hline \\
\hline \multicolumn{2}{|l|}{ 1.1.1.4 } \\
\hline \multicolumn{2}{|l|}{ 1.1.1.5 } \\
\hline \\
\hline \multicolumn{2}{|l|}{ 1.1.1.7 } \\
\hline & Reactivity Control System (RCS) \\
\hline & RCS - Control Rods \\
\hline 1.1 .2 .2 & RCS - Control Rods Plenum \\
\hline \multirow{2}{*}{\multicolumn{2}{|c|}{ RCS - Control Interconnect }} \\
\hline & \\
\hline \multicolumn{2}{|l|}{ 1.1.3.1 } \\
\hline \multicolumn{2}{|l|}{ 1.1.3.2 } \\
\hline & Neutron Control Equipment \\
\hline & Nuclear Instrumentation \\
\hline & ReactorVessel Internals \\
\hline & \\
\hline 1.1.4.2 & Upper Closure Head \\
\hline & Bottom Head \\
\hline & Upper Core Restraint \\
\hline 1.1.4.5 & Permanent Side Reflectors \\
\hline & Metallic Core Support \\
\hline & Permanent Bottom Reflectors \\
\hline 1.1.4.8 & Lower Floor Blocks \\
\hline \multirow{2}{*}{$\begin{array}{l}1.1 .4 .9 \\
1.1 .4 .10\end{array}$} & Main Vessel \\
\hline & Sealing Device \\
\hline 1.1.4.11 & Graphite Core Support Structure \\
\hline \multirow{2}{*}{$\begin{array}{l}1.1 .4 .12 \\
1.1 .5\end{array}$} & Top Plenum Shroud Structure \\
\hline & Core Internal Structure (metallic, graphite, ceramic) \\
\hline \multirow{2}{*}{$\begin{array}{l}1.1 .6 \\
1.1 .6 .1 \\
1.1 .6 .2\end{array}$} & Fuel Elements (spheres) \\
\hline & \\
\hline \multicolumn{2}{|l|}{ 1.1.6. } \\
\hline & IHX Pressure Vessel \\
\hline & Main Vessel \\
\hline
\end{tabular}

\begin{tabular}{|c|c|}
\hline Hierarchy & GA PREFERRED TRL SSCs \\
\hline 1 & Nuclear Heat Supply System (NHSS) \\
\hline & Reactor Unit System \\
\hline & Reactor Pressure Vessel (RPV) \\
\hline \multicolumn{2}{|l|}{ 1.1.1.1 } \\
\hline \multirow{2}{*}{\multicolumn{2}{|c|}{$\begin{array}{l}1.1 .1 .2 \\
1.1 .1 .3\end{array}$}} \\
\hline & \\
\hline \multicolumn{2}{|l|}{ 1.1.1.4 } \\
\hline \multicolumn{2}{|l|}{1.1 .1 .5} \\
\hline \multicolumn{2}{|l|}{ 1.1.1.6 } \\
\hline \multicolumn{2}{|l|}{ 1.1.1.7 } \\
\hline & Reactivity Control System (RCS) \\
\hline & RCS - Control Rods \\
\hline 1.1.2.2 & RCS - Control Rods Plenum \\
\hline & RCS - Control Interconnect \\
\hline & RPV- Neutron Control SubSystem \\
\hline 1.1.3.1 & Outer and Inner Neutron Control Assemblie \\
\hline & Neutron Source Range Detector Assemblies \\
\hline & RPV- Neutron Control Assembly \\
\hline \multicolumn{2}{|l|}{ 1.1.3.4 } \\
\hline & Reactor Core (Including Graphite) \\
\hline & \\
\hline \multicolumn{2}{|l|}{ 1.1.4.2 } \\
\hline \\
\hline \multirow{2}{*}{$\begin{array}{l}1.1 .4 .5 \\
1.1 .4 .6 \\
1.1 .4 .7\end{array}$} & Permanent Side Reflectors \\
\hline & \\
\hline 1.1.4.7 & Permanent Bottom Reflectors \\
\hline \multicolumn{2}{|l|}{ 1.1.4.8 } \\
\hline \multicolumn{2}{|l|}{1.1 .4 .9} \\
\hline \multicolumn{2}{|l|}{1.1 .4 .10} \\
\hline \multirow{3}{*}{$\begin{array}{l}1.1 .4 .11 \\
1.1 .4 .12 \\
1.1 .5\end{array}$} & Graphite Core support structure \\
\hline & \\
\hline & Reactor Internals \\
\hline \multirow{4}{*}{$\begin{array}{l}1.1 .6 \\
1.1 .6 .1 \\
1.1 .6 .2 \\
1.1 .7 \\
1.1 .7 .1\end{array}$} & Fuel Elements (spheres) \\
\hline & \\
\hline & \\
\hline & \\
\hline
\end{tabular}




\begin{tabular}{|c|c|}
\hline Hierarchy & NGNP TRL MASTER COPY \\
\hline 1.1.7.2 & Insulation \\
\hline 1.2 & Core Conditioning System (CCS) \\
\hline 1.2 .1 & CCS Blower \\
\hline 1.2 .2 & CCS Heat Exchanger \\
\hline 1.2.2.1 & CCS HX Core \\
\hline 1.2.2.2. & CCS HX vessel Insulation \\
\hline 1.2.2.3 & CCS Vessel, Including External Supports \\
\hline 1.2 .3 & CCS Valves \\
\hline 1.2 .4 & CCS Piping \\
\hline 1.2 .5 & Internal Ducts, Supports and Insulation \\
\hline 1.2 .6 & Other CCS Subsystems \\
\hline 1.3 & Reactor Cavity Cooling System \\
\hline 1.3 .1 & Storage Tank \\
\hline 1.3 .2 & Coolant Piping \\
\hline 1.3 .3 & Water Storage Tank \\
\hline 1.3 .4 & Water-to-Water Heat Exchanger \\
\hline 1.3 .5 & Cavity Cooler Panels \\
\hline 1.3 .6 & Water-to- Air Heat Exchanger \\
\hline 1.4 & $\begin{array}{l}\text { Fuel Handling and Storage System (including } \\
\text { fuel receipt) }\end{array}$ \\
\hline 1.4 .1 & Fuel Storage pools \\
\hline 1.4 .2 & Fuel Storage wells 0r Fuel Storage server \\
\hline 1.4.3 & Fuel Handling Machine \\
\hline 1.4 .4 & Fuel Elevator \\
\hline 1.4.5 & Fuel Adapter \\
\hline 1.4 .3 & High-level Waste Handling Subsystem \\
\hline 1.4 .4 & Fuel (Sphere) Circulation Subsystems \\
\hline 1.4 .5 & Fuel (Sphere) Replenish Subsystem \\
\hline 1.4 .6 & Fuel Handling Control Subsystem \\
\hline 1.4 .7 & Circulating Gas Subsystem \\
\hline 1.4.8 & Fuel(Sphere) Decommissioning Subsystem \\
\hline 1.4 .9 & Auxiliary Gas Subsystem \\
\hline 1.4 .10 & Burn-up Measurement System \\
\hline 1.5 & Spent Fuel Storage System \\
\hline 1.5 .1 & Local Spent Fuel Storage \\
\hline 1.5 .2 & Core Off load Storage \\
\hline 1.5 .3 & Intermediate Term Spent Fuel Storage \\
\hline 1.6 & Spent Fuel Cooling System \\
\hline 1.6.1 & Water Pool \\
\hline 1.6.2 & Circulating Pump \\
\hline 1.6 .3 & Water-to-Air Heat Exchanger \\
\hline 1.6 .4 & Piping \\
\hline 1.7 & Nuclear Island Cooling System \\
\hline 1.7 .1 & Circulating Pumps \\
\hline
\end{tabular}

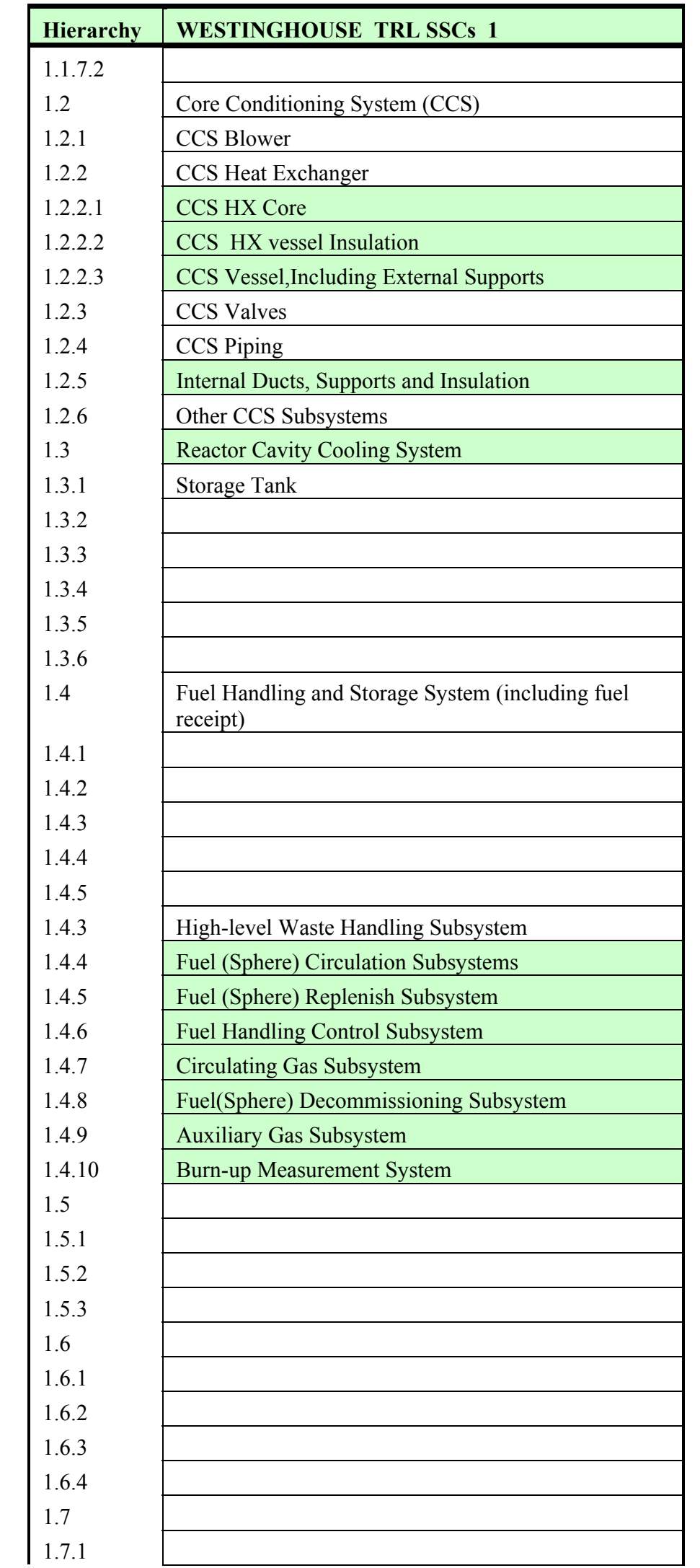

\begin{tabular}{|c|c|}
\hline Hierarchy & AREVA PREFERRED TRL SSCs 1 \\
\hline \multirow{4}{*}{$\begin{array}{l}1.1 .7 .2 \\
1.2 \\
1.2 .1 \\
1.2 .2\end{array}$} & Insulation \\
\hline & Core Conditioning System (CCS) \\
\hline & CCS Blower \\
\hline & CCS Heat Exchanger \\
\hline \\
\hline \multicolumn{2}{|l|}{1.2 .2 .2} \\
\hline \multicolumn{2}{|l|}{1.2 .2 .3} \\
\hline & CCS Valves \\
\hline 1.2 .4 & CCS Piping \\
\hline \multicolumn{2}{|l|}{ 1.2.5 } \\
\hline 1.2.6 & Other CCS Subsystems \\
\hline $\begin{array}{l}1.2 .0 \\
1.3\end{array}$ & Reactor Cavity Cooling System \\
\hline & Water Storage Tank \\
\hline & Cooling Piping \\
\hline 1.3 .3 & Water Storage Tank \\
\hline & Water-to-Water Heat Exchanger \\
\hline & Cavity Cooler Panels \\
\hline \multirow{2}{*}{$\begin{array}{l}1.3 .6 \\
1.4\end{array}$} & Water-to- Air Heat Exchanger \\
\hline & Fuel Handling System \\
\hline \multicolumn{2}{|l|}{ 1.4.1 } \\
\hline \multicolumn{2}{|l|}{ 1.4.2 } \\
\hline & Fuel Handling Machine \\
\hline & Fuel Elevator \\
\hline 1.4 .5 & Fuel Adapter \\
\hline \multirow{2}{*}{$\begin{array}{l}1.4 .3 \\
1.4 .4\end{array}$} & High-level Waste Handling Subsystem \\
\hline & \\
\hline \multicolumn{2}{|l|}{1.4 .5} \\
\hline \multicolumn{2}{|l|}{ 1.4.6 } \\
\hline \multicolumn{2}{|l|}{ 1.4.7 } \\
\hline \multicolumn{2}{|l|}{ 1.4.9 } \\
\hline \multicolumn{2}{|l|}{ 1.4.10 } \\
\hline \multirow{3}{*}{$\begin{array}{l}1.5 \\
1.5 .1 \\
1.5 .2\end{array}$} & Spent Fuel Storage System \\
\hline & Local Spent Fuel Storage \\
\hline & Core Off load Storage \\
\hline \multirow{2}{*}{$\begin{array}{l}1.5 .3 \\
1.6\end{array}$} & Intermediate Term Spent Fuel Storage \\
\hline & Spent Fuel Cooling System \\
\hline \multirow{2}{*}{$\begin{array}{l}1.6 .1 \\
1.6 .2\end{array}$} & Water Pool \\
\hline & Circulating Pump \\
\hline \multirow{2}{*}{1.6 .3} & Water-to-Air Heat Exchanger \\
\hline & Piping \\
\hline \multirow{2}{*}{$\begin{array}{l}1.7 \\
1.7 .1\end{array}$} & Nuclear Island Cooling System \\
\hline & Circulating Pumps \\
\hline
\end{tabular}




\begin{tabular}{|c|c|}
\hline Hierarchy & NGNP TRL MASTER COPY \\
\hline 1.7 .2 & Water-to Air Heat Exchanger \\
\hline 1.7 .3 & Piping \\
\hline 1.8 & Other Subsystems \\
\hline 1.9 & Helium Service System \\
\hline 1.9 .1 & Constituents Control \\
\hline 1.9 .2 & Piping Internals \\
\hline 1.9 .3 & PTHS Inventory Control Subsystem \\
\hline 1.9 .4 & SHTS Inventory Control Subsystem \\
\hline 1.9 .5 & PTHS Helium Purification Subsystem \\
\hline 1.9 .6 & SHTS Helium Purification Subsystem \\
\hline 1.9.6.1 & Dust Removal Filter \\
\hline 1.9.6.2 & Heater \\
\hline 1.9 .6 .3 & Copper Oxide Bed \\
\hline 1.9.6.4 & Recuperative Heat Exchanger \\
\hline 1.9 .6 .5 & He-to-Water Heat Exchanger \\
\hline 1.9.6.6 & Water Separator \\
\hline 1.9.6.7 & Molecular Sieve \\
\hline 1.9.6.8 & Low Temperature Absorber \\
\hline 1.9.6.9 & Blower \\
\hline 1.9 .7 & Auxiliary Systems (Including Helium Cleanup) \\
\hline 1.9 .8 & Chemistry Control Systems \\
\hline 1.9 .9 & Controls \& Instrumentations \\
\hline 1.9 .10 & Helium Make-up System \\
\hline 1.10 & NHSS Control and Instrumentation System \\
\hline 1.10 .1 & Operational Control System \\
\hline 1.10 .2 & Reactor Protection System \\
\hline 1.10 .3 & Equipment Protection System \\
\hline 1.10 .4 & Post-event Monitoring and Recovery System \\
\hline 1.10 .5 & Uniterruptible Power System \\
\hline 1.11 & Nuclear Cooling Systems \\
\hline 1.11 .1 & Auxiliary Component Cooling Water System \\
\hline 1.11.2 & $\begin{array}{l}\text { Equipment Protection Cooling Circuit(Back up } \\
\text { heat sink }\end{array}$ \\
\hline 1.11 .3 & $\begin{array}{l}\text { Servicing Equipment for Heat Exchanger and } \\
\text { Circulator }\end{array}$ \\
\hline 1.11 .4 & Reserve Shutdown System \\
\hline 1.11.4.1 & Spherical Absorber Elements \\
\hline 1.11.4.2 & Element Hopper \\
\hline 1.11.4.3 & Gates \\
\hline 1.11.4.4 & Guide Tube \\
\hline 1.11 .5 & Start-Up and Decay Heat Removal System \\
\hline 1.11.5.1 & Valves \\
\hline 1.11.5.2 & He-to-Air Heat Exchanger \\
\hline 1.11.5.3 & He Circulator \\
\hline
\end{tabular}

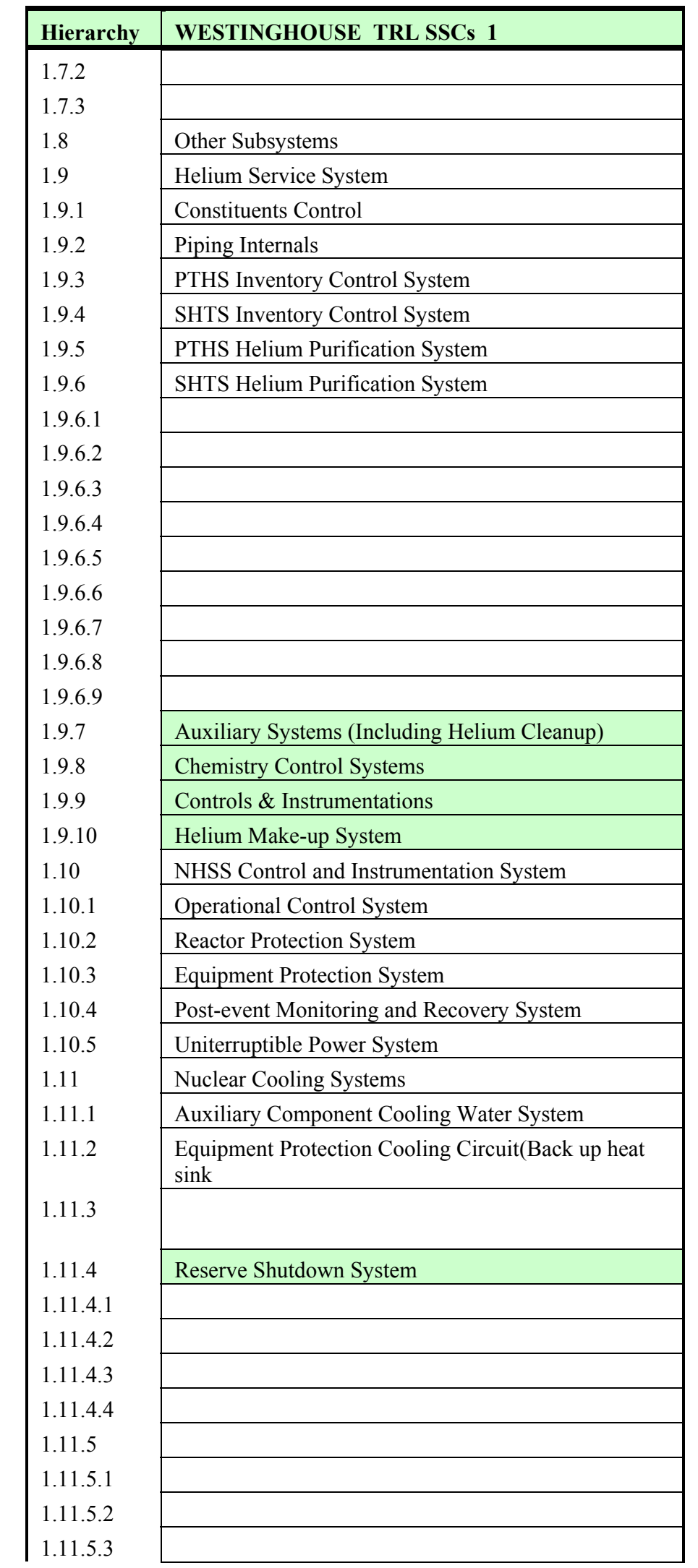

\begin{tabular}{|c|c|}
\hline Hierarchy & AREVA PREFERRED TRL SSCs 1 \\
\hline \multirow{40}{*}{$\begin{array}{l}1.7 .2 \\
1.7 .3 \\
1.8 \\
1.9 \\
1.9 .1 \\
1.9 .2 \\
1.9 .3 \\
1.9 .4 \\
1.9 .5 \\
1.9 .6 \\
1.9 .6 .1 \\
1.9 .6 .2 \\
1.9 .6 .3 \\
1.9 .6 .4 \\
1.9 .6 .5 \\
1.9 .6 .6 \\
1.9 .6 .7 \\
1.9 .6 .8 \\
1.9 .6 .9 \\
1.9 .7 \\
1.9 .8 \\
1.9 .9 \\
1.9 .10 \\
1.10 \\
1.10 .1 \\
1.10 .2 \\
1.10 .3 \\
1.10 .4 \\
1.10 .5 \\
1.11 \\
1.11 .1 \\
1.11 .2 \\
1.11 .3 \\
1.11 .4 \\
1.11 .4 .1 \\
1.11 .4 .2 \\
1.11 .4 .3 \\
1.11 .4 .4 \\
1.11 .5 \\
1.11 .5 .1 \\
1.11 .5 .2 \\
1.11 .5 .3\end{array}$} & Water-to Air Heat Exchanger \\
\hline & Piping \\
\hline & Other Subsystems \\
\hline & Helium Service System \\
\hline & Constituents Control \\
\hline & Piping Internals \\
\hline & PTHS Inventory Control System \\
\hline & SHTS Inventory Control System \\
\hline & PTHS Helium Purification System \\
\hline & SHTS Helium Purification System \\
\hline & Dust Removal Filter \\
\hline & Heater \\
\hline & Copper Oxide Bed \\
\hline & Recuperative Heat Exchanger \\
\hline & He-to-Water Heat Exchanger \\
\hline & Water Separator \\
\hline & Molecular Sieve \\
\hline & Low Temperature Absorber \\
\hline & Blower \\
\hline & \\
\hline & \\
\hline & \\
\hline & NHSS Control and Instrumentation System \\
\hline & Operational Control System \\
\hline & Reactor Protection System \\
\hline & Equipment Protection System \\
\hline & Post-event Monitoring and Recovery System \\
\hline & Uniterruptible Power System \\
\hline & Nuclear Cooling Systems \\
\hline & Auxiliary Component Cooling Water System \\
\hline & Equipment Protection Cooling Circuit(Back up heat sink \\
\hline & \\
\hline & \\
\hline & Spherical Absorber Elements \\
\hline & Element Hopper \\
\hline & Gates \\
\hline & Guide Tube \\
\hline & Start-Up and Decay Heat Removal System \\
\hline & Valves \\
\hline & He-to-Air Heat Exchanger \\
\hline
\end{tabular}




\begin{tabular}{|c|c|}
\hline Hierarchy & NGNP TRL MASTER COPY \\
\hline \multirow{42}{*}{$\begin{array}{l}1.11 .5 .4 \\
1.11 .5 .5 \\
1.11 .5 .6 \\
1.11 .6 \\
1.11 .6 .1 \\
1.11 .6 .2 \\
1.11 .6 .3 \\
1.11 .6 .4 \\
1.11 .6 .5 \\
1.11 .6 .6 \\
1.11 .6 .7 \\
1.11 .7 \\
1.11 .7 .1 \\
1.11 .7 .2 \\
1.11 .7 .3 \\
1.11 .7 .4 \\
1.11 .7 .5 \\
1.11 .7 .6 \\
1.11 .7 .7 \\
1.11 .7 .8 \\
1.11 .8 \\
1.11 .9 \\
1.12 \\
1.12 .1 \\
1.12 .2 \\
1.12 .3 \\
1.13 \\
1.14 \\
1.15 \\
1.15 .1 \\
1.15 .2 \\
1.15 .3 \\
1.16 \\
1.16 .1 \\
1.16 .2 \\
\\
2 \\
2.1 \\
2.1 .1 \\
2.11 .1 \\
2.11 .2 \\
2.11 .3 \\
2.1 .1 .4\end{array}$} & Piping \\
\hline & Cooling panels \\
\hline & Inlet/Outlet Ducts Structures \\
\hline & Cross Vessel \\
\hline & Internal Ducts, Supports and Insulation \\
\hline & Concentric Duct System \\
\hline & Hot leg/cold leg \\
\hline & Ceramic Fiber Insulation \\
\hline & Connection to IHX Pressure Vessel \\
\hline & Connection to RPV \\
\hline & Main Vessel \\
\hline & Reactor Shut Down Cooling System \\
\hline & He Circulator \\
\hline & Water Loop Piping \\
\hline & Water Loop Pump \\
\hline & Air Blowers \\
\hline & Shut off Valve \\
\hline & Heat Exchanger \\
\hline & Control System \\
\hline & Shutdown Cooling Water System \\
\hline & Other Subsystems \\
\hline & Other NHSS Systems \\
\hline & NHSS Electrical Distribution System \\
\hline & Plant Main AC Power Supply \\
\hline & DC and Uninterruptible Power Supply \\
\hline & Plant Standby Power Supply \\
\hline & Reactor Building HVAC System \\
\hline & Primary Loop Initial Cleanup System \\
\hline & Pressure boundary support systems \\
\hline & De-Fuel Chute Cooling System \\
\hline & Vessel Over-Pressure System \\
\hline & Inertial Dust Filter \\
\hline & NHSS Cooling Water System \\
\hline & Auxiliary Component Cooling Water System \\
\hline & $\begin{array}{l}\text { Equipment Protectjon Cooling Circuit(Including } \\
\text { Backup Heat Sink) }\end{array}$ \\
\hline & Heat Transfer System (HTS) \\
\hline & Primary Heat Transport System (PHTS) \\
\hline & PHTS Circulator \\
\hline & Housing \\
\hline & Inverter \\
\hline & Rotor \\
\hline & Impeller \& shaft \\
\hline
\end{tabular}

\begin{tabular}{|c|c|}
\hline Hierarchy & WESTINGHOUSE TRL SSCs 1 \\
\hline \\
\hline \multicolumn{2}{|l|}{ 1.11.5.5 } \\
\hline \\
\hline & Cross Vessel \\
\hline & Internal Ducts, Supports and Insulation \\
\hline \multicolumn{2}{|l|}{ 1.11.6.2 } \\
\hline \multicolumn{2}{|l|}{ 1.11.6.3 } \\
\hline \multicolumn{2}{|l|}{ 1.11.6.4 } \\
\hline \multirow{2}{*}{\multicolumn{2}{|c|}{$\begin{array}{l}1.11 .6 .5 \\
1.65\end{array}$}} \\
\hline & \\
\hline \multicolumn{2}{|l|}{ 1.11.6.7 } \\
\hline \multicolumn{2}{|r|}{ Reactor Shut Down Cooling System } \\
\hline \multicolumn{2}{|l|}{ 1.11.7.1 } \\
\hline \multirow{2}{*}{\multicolumn{2}{|c|}{$\begin{array}{l}1.11 .7 .2 \\
1.11 .7 .\end{array}$}} \\
\hline & \\
\hline \multicolumn{2}{|l|}{1.11 .7 .4} \\
\hline \multicolumn{2}{|l|}{ 1.11.7.5 } \\
\hline \multicolumn{2}{|l|}{ 1.11.7.6 } \\
\hline \multicolumn{2}{|l|}{ 1.11.7.7 } \\
\hline \multicolumn{2}{|l|}{1.11 .7 .8} \\
\hline & Other Subsystems \\
\hline & Other NHSS Systems \\
\hline \multirow{2}{*}{\multicolumn{2}{|c|}{ NHSS Electrical Distribution System }} \\
\hline & \\
\hline \multicolumn{2}{|l|}{1.12 .2} \\
\hline \multicolumn{2}{|l|}{1.12 .3} \\
\hline 1.13 & Reactor Building HVAC System \\
\hline \multirow{4}{*}{$\begin{array}{l}1.14 \\
1.15 \\
1.15 .1 \\
1.15 .2\end{array}$} & Primary Loop Initial Cleanup System \\
\hline & Pressure boundary support systems \\
\hline & De-Fuel Chute Cooling System \\
\hline & Vessel Over-Pressure System \\
\hline & Inertial Dust Filter \\
\hline & NHSS Cooling Water System \\
\hline & Auxiliary Component Cooling Water System \\
\hline & $\begin{array}{l}\text { Equipment Protectjon Cooling Circuit(Including } \\
\text { Backup Heat Sink) }\end{array}$ \\
\hline 2 & Heat Transfer System (HTS) \\
\hline \multirow{2}{*}{$\begin{array}{l}2.1 \\
2.1 .1\end{array}$} & Primary Heat Transport System (PHTS) \\
\hline & PHTS Circulator \\
\hline \multicolumn{2}{|l|}{ 2.1.1.1 } \\
\hline 2.1.1.2 & \\
\hline 2.1.1.3 & \\
\hline 2.1.1.1.4 & Impeller \& shaft \\
\hline
\end{tabular}

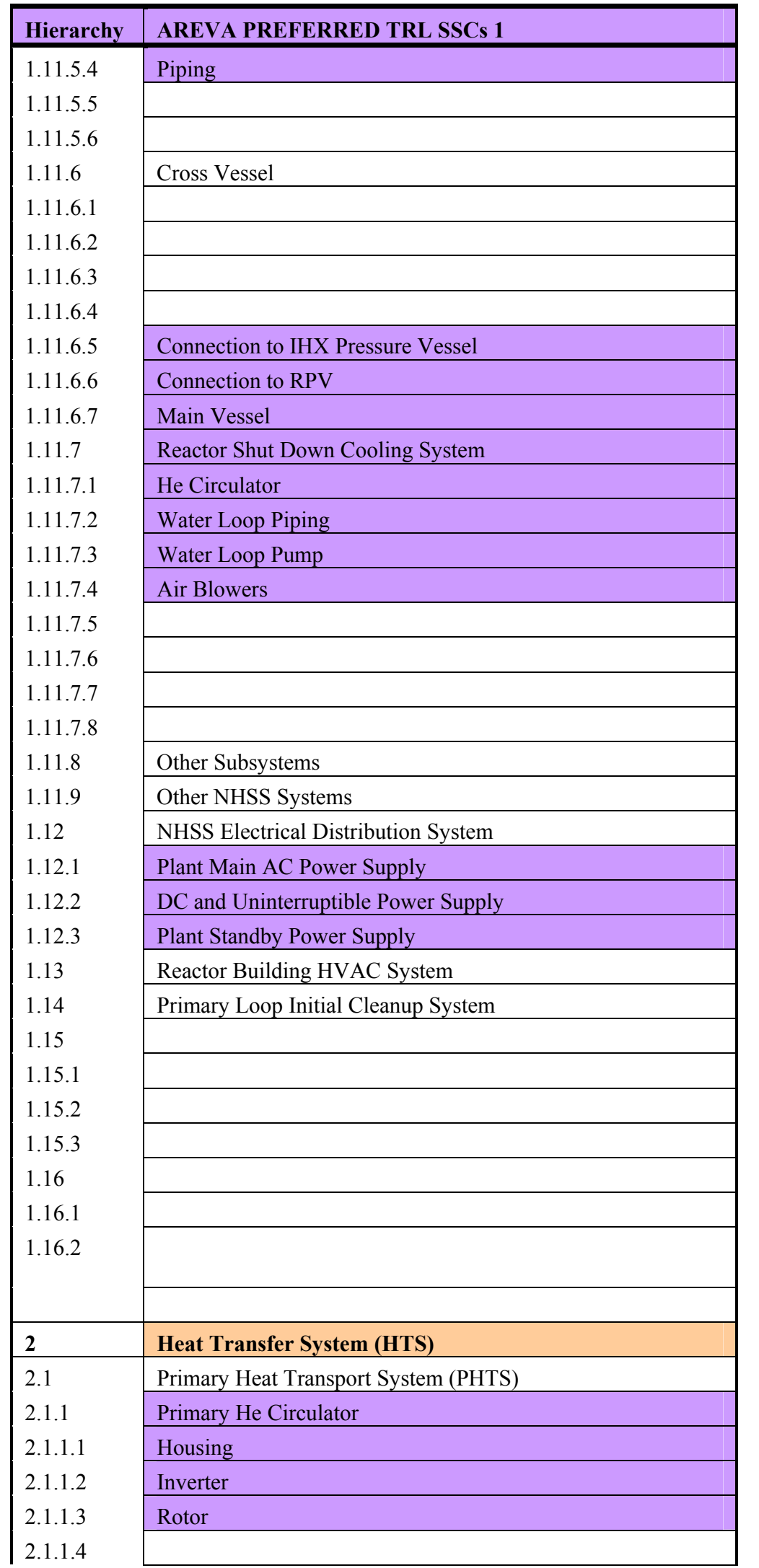

\begin{tabular}{|c|c|}
\hline Hierarchy & GA PREFERRED TRL SSCs \\
\hline \multirow{5}{*}{$\begin{array}{l}1.11 .5 .4 \\
1.11 .5 .5 \\
1.11 .5 .6 \\
1.11 .6 \\
1.11 .6 .1\end{array}$} & \\
\hline & Cooling panels \\
\hline & Inlet/Outlet Ducts Structures \\
\hline & Cross Vessel \\
\hline & \\
\hline \multirow{2}{*}{$\begin{array}{l}1.11 .6 .2 \\
1.11 .6 .3\end{array}$} & Concentric Duct System \\
\hline & Hot leg/cold leg \\
\hline \multirow{3}{*}{$\begin{array}{l}1.11 .6 .4 \\
1.11 .6 .5 \\
1.11 .6 .6\end{array}$} & Ceramic Fiber Insulation \\
\hline & \\
\hline & \\
\hline \multirow{3}{*}{$\begin{array}{l}1.11 .6 .7 \\
1.11 .7 \\
1.11 .7 .1\end{array}$} & \\
\hline & Reactor Shut Down Cooling System \\
\hline & \\
\hline \multicolumn{2}{|l|}{ 1.11.7.2 } \\
\hline \multirow{2}{*}{\multicolumn{2}{|c|}{ 1.11.7.3 }} \\
\hline & \\
\hline $\begin{array}{l}1.11 .7 .4 \\
1.11 .7 .5\end{array}$ & Shut off Valve \\
\hline 1.11 .7 .6 & Heat Exchanger \\
\hline \multirow{2}{*}{$\begin{array}{l}1.11 .7 .7 \\
1.11 .7 .8\end{array}$} & Control System \\
\hline & Shutdown Cooling Water System \\
\hline 1.11 .8 & Other Subsystems \\
\hline & Other NHSS Systems \\
\hline & NHSS Electrical Distribution System \\
\hline \multicolumn{2}{|l|}{1.12 .1} \\
\hline \\
\hline & \\
\hline \multirow{2}{*}{$\begin{array}{l}1.13 \\
1.14\end{array}$} & Reactor Building HVAC System \\
\hline & Primary Loop Initial Cleanup System \\
\hline \multicolumn{2}{|r|}{. } \\
\hline \multicolumn{2}{|l|}{1.15 .1} \\
\hline \multicolumn{2}{|l|}{$\begin{array}{l}1.15 .2 \\
1.15 .3\end{array}$} \\
\hline \\
\hline \multicolumn{2}{|l|}{1.16 .1} \\
\hline \\
\hline 2 & Heat Transfer System (HTS) \\
\hline \multirow{2}{*}{$\begin{array}{l}2.1 \\
2.1 .1\end{array}$} & Primary Heat Transport System (PHTS) \\
\hline & PHTS Circulator (Helium Circulator) \\
\hline 2.1.1.1 & \\
\hline 2.1 .1 .2 & \\
\hline 2.1.1.3 & \\
\hline 2.1.1.4 & \\
\hline
\end{tabular}




\begin{tabular}{|c|c|}
\hline Hierarchy & NGNP TRL MASTER COPY \\
\hline 2.1.1.5 & Seals \\
\hline 2.1.1.6 & Motor \\
\hline 2.1.1.7 & Instrumentation and Control (Motor and EMB) \\
\hline 2.1.1.8 & Magnetic Bearings \\
\hline 2.1.1.9 & Inverter \\
\hline 2.1.1.10 & Bearings (Electromagnetic bearings and support) \\
\hline 2.1 .2 & PHTS Valve (High Temperature Flapper Valve) \\
\hline 2.1.2.1 & Flapper Valve \\
\hline 2.1.2.2 & Housing \\
\hline 2.1.2.3 & Valve Seat \\
\hline 2.1.2.4 & Valve Stem \\
\hline 2.1.2.5 & Valve Actuation Mechanism \\
\hline 2.1 .3 & WEC,AREVA,GA IHX OPTIONS \\
\hline 2.1.3.1 & \\
\hline 2.1.3.2 & \\
\hline $\begin{array}{l}2.1 .3 .3 \\
2.1 .3 .3\end{array}$ & PHTS Piping (Reactor to IHX) \\
\hline 2.1.3.4 & AREVA IHX OPTION \\
\hline 2.1.3.5 & \\
\hline 2.1.3.6 & \\
\hline 2.1.3.7 & \\
\hline 2.1.3.8 & \\
\hline 2.1.3.9 & \\
\hline 2.1.3.10 & \\
\hline 2.1.3.11 & Shafts \\
\hline 2.1.3.12 & $\begin{array}{l}\text { PHTS Pressure Boundary Piping, Including } \\
\text { External Supports and Insulation }\end{array}$ \\
\hline 2.1.3.13 & Piping from Circulator to Reactor Inlet \\
\hline 2.1.3.14 & Piping from IHX to Circulator \\
\hline 2.1.3.15 & Other Heat Exchanger equipment \\
\hline 2.1.3.16 & External supports \\
\hline 2.1 .4 & WEC IHX OPTION A \\
\hline 2.1.4.1 & \\
\hline 2.1.4.2 & \\
\hline 2.1.4.3 & \\
\hline 2.1.4.4 & Motor \\
\hline 2.1.4.5 & Bearings (Electromagnetic bearings and support) \\
\hline 2.1.4.6 & PHTS Piping (Reactor to IHX) \\
\hline 2.1.4.7 & Shafts \\
\hline 2.1.4.8 & $\begin{array}{l}\text { PHTS Pressure Boundary Piping, Including } \\
\text { External Supports and Insulation }\end{array}$ \\
\hline
\end{tabular}

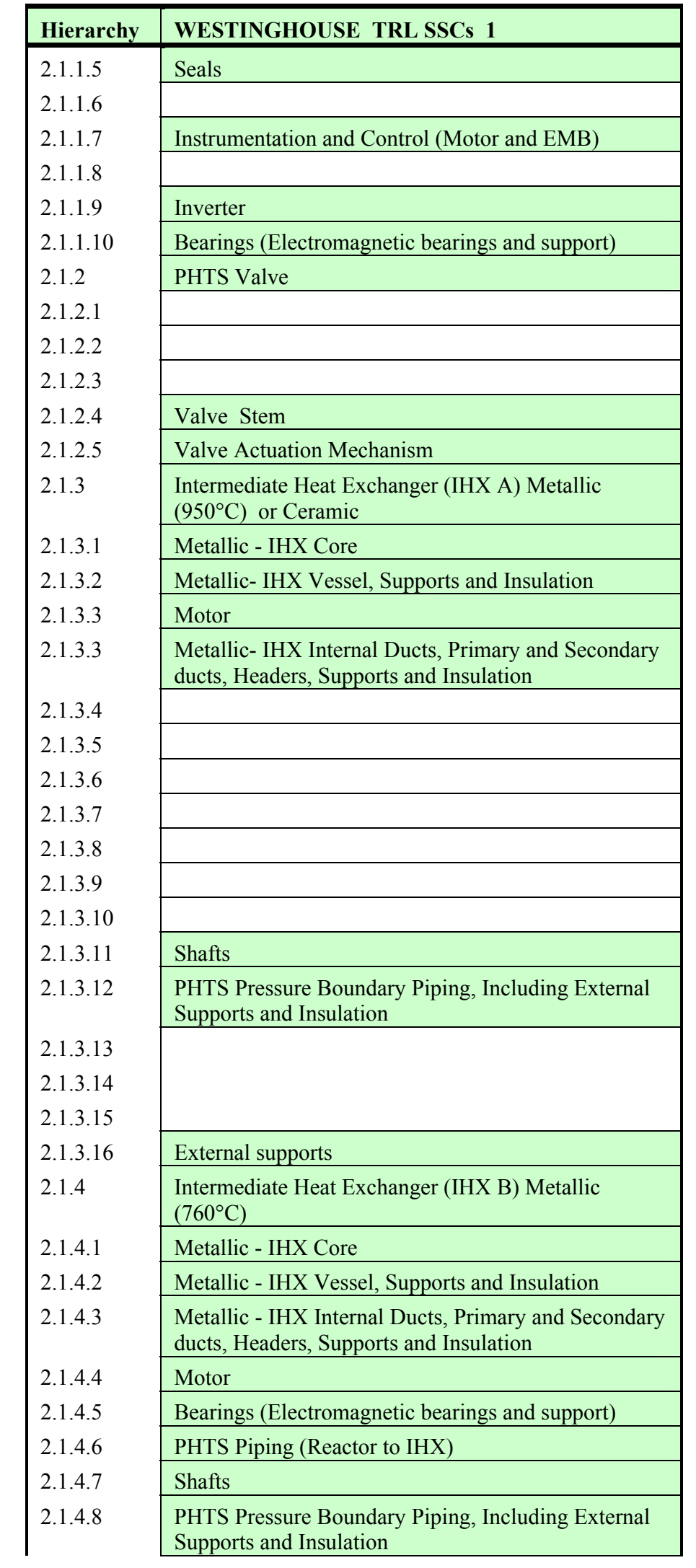

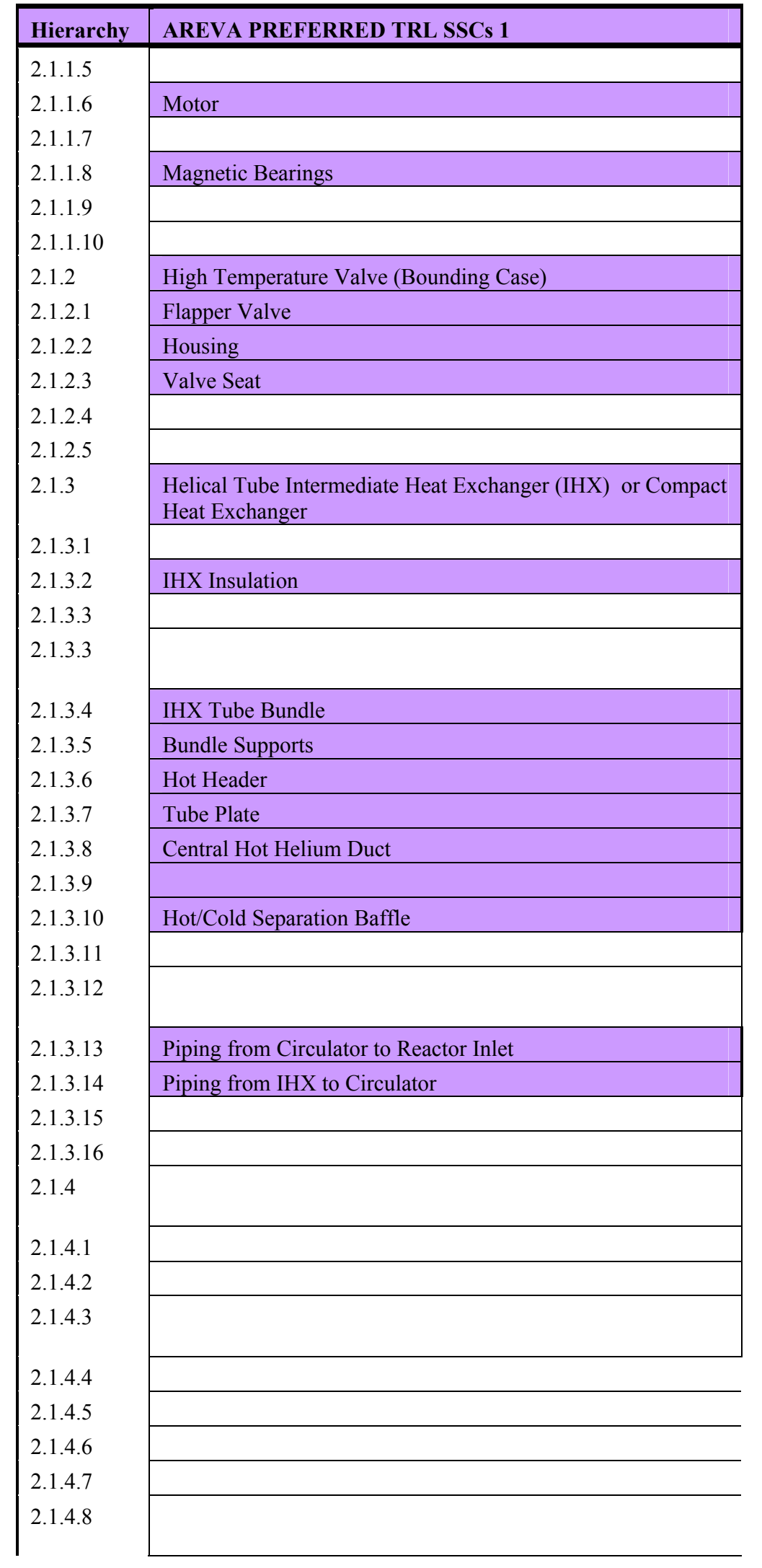




\begin{tabular}{|c|c|}
\hline Hierarchy & NGNP TRL MASTER COPY \\
\hline 2.1 .5 & $\begin{array}{l}\text { Piping (primary circuit from Reactor to IHX and } \\
\text { between IHX vessels -both hot and cold legs }\end{array}$ \\
\hline 2.1.5.1 & $\begin{array}{l}\text { PHTS Pressure Boundary Piping, Including } \\
\text { External Supports and Insulation }\end{array}$ \\
\hline 2.1.5.2 & $\begin{array}{l}\text { PHTS Piping Internal Ducts, Supports and } \\
\text { Insulation }\end{array}$ \\
\hline 2.1.6 & Pressure Relief System \\
\hline 2.1.6.1 & Pressure Relief Valve \\
\hline 2.1 .7 & Primary Hot Duct \\
\hline 2.1.7.1 & Duct Liner \\
\hline 2.1.7.2 & Duct Support Tube \\
\hline 2.1.7.3 & Insulation \\
\hline 2.1.7.4 & Perforated Pipe with Mesh Cover \\
\hline 2.1.7.5 & Intermediate Foil \\
\hline 2.2 & Secondary Heat Transport System (SHTS) \\
\hline 2.2 .1 & SHTS Circulator \\
\hline 2.2.1.1 & Ceramic Fiber Insulation \\
\hline 2.2.1.2 & Other Heat exchanger equipment \\
\hline 2.2.1.3 & Piping Internal Ducts, Supports and Insulation \\
\hline 2.2.1.4 & Housing \\
\hline 2.2.1.5 & Inverter \\
\hline 2.2.1.6 & Rotor \\
\hline 2.2.1.7 & Impeller \& shaft \\
\hline 2.2.1.8 & Motor \\
\hline 2.2.1.9 & Seals \\
\hline 2.2.1.10 & Bearings \\
\hline 2.2 .2 & SHTS Valve (High Temperature Flapper Valve) \\
\hline 2.2.2.1 & Flapper Valve \\
\hline 2.2.2.2. & Housing \\
\hline 2.2.2.3 & Valve Seat \\
\hline 2.2.3 & Primary Hot Duct \\
\hline 2.2.3.1 & Duct Liner \\
\hline 2.2.3.2 & Duct Support \\
\hline 2.2.3.3 & Insulation \\
\hline 2.2 .4 & Piping (both hot and cold legs, plus PCHX to SG) \\
\hline 2.2.4.1 & $\begin{array}{l}\text { Pressure Boundary Piping, Including External } \\
\text { Supports and Insulation }\end{array}$ \\
\hline 2.2.4.2 & Piping Internal Ducts, Supports and Insulation \\
\hline 2.2 .5 & Helium Isolation Valves \\
\hline 2.2 .6 & SHTS Flow Coupling and Mixer \\
\hline 2.2.6.1 & Mixing Chamber \\
\hline 2.2.6.2 & Chamber Inner walls Insulation \\
\hline 2.2.6.3 & Vibration Damping Devices \\
\hline
\end{tabular}

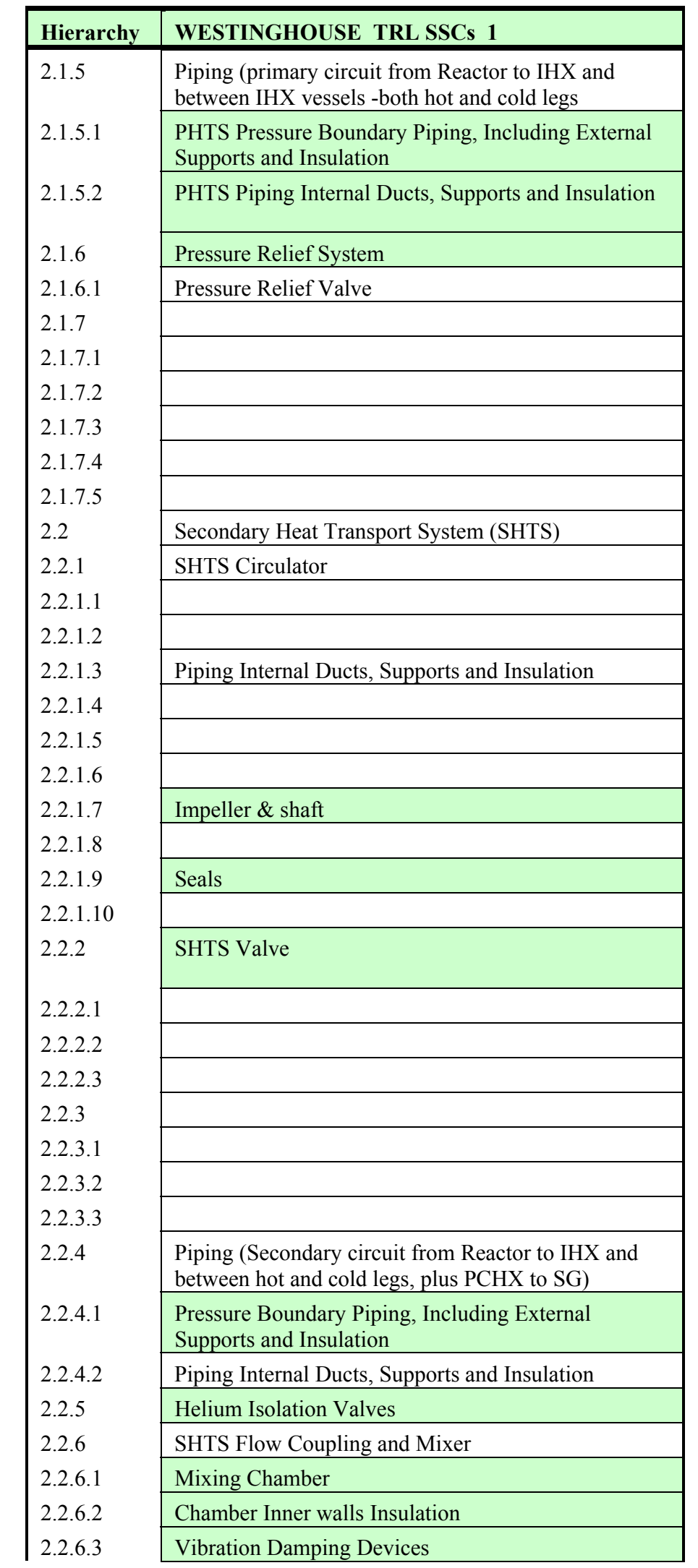

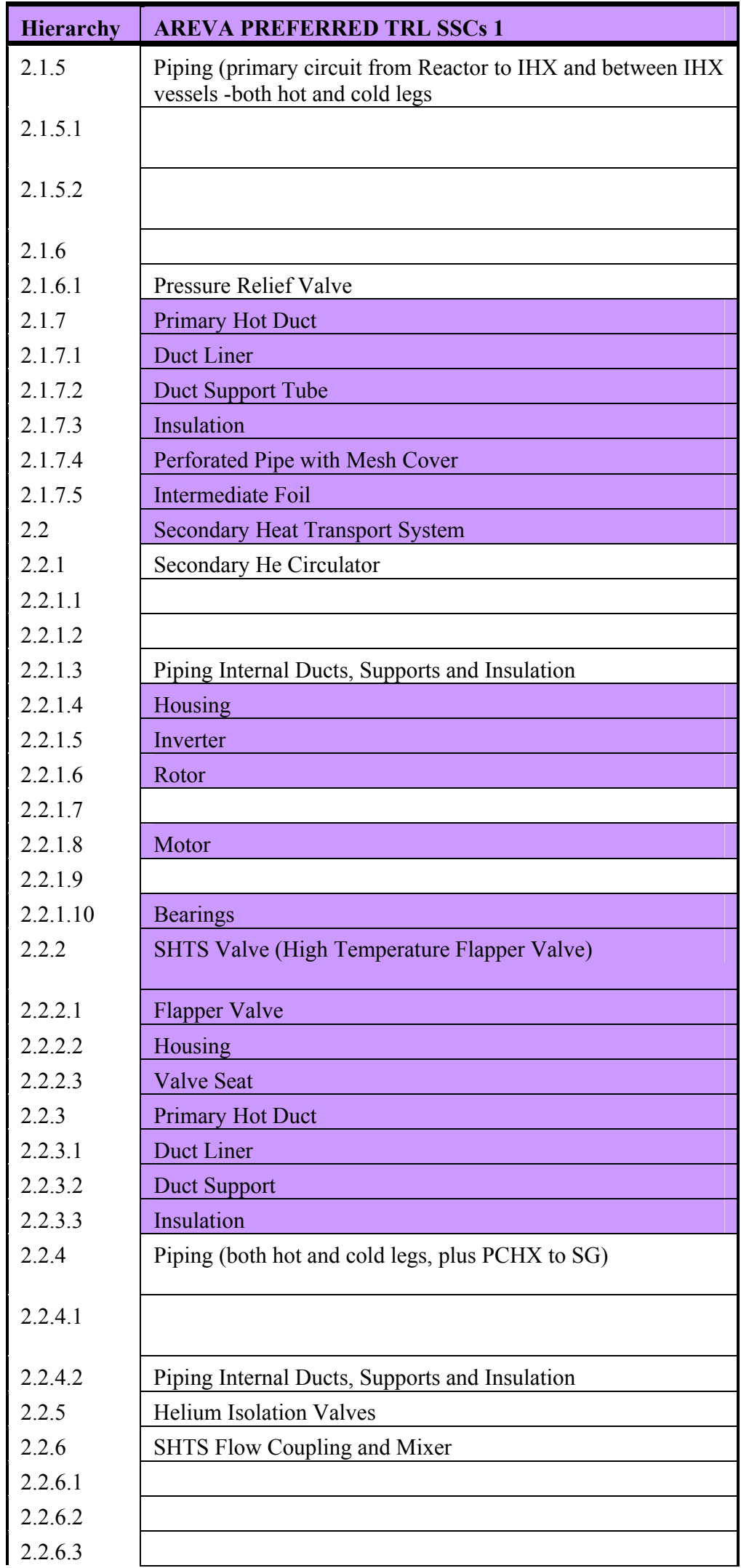




\begin{tabular}{|c|c|}
\hline Hierarchy & NGNP TRL MASTER COPY \\
\hline \multirow{17}{*}{$\begin{array}{l}2.2 .7 \\
2.2 .7 .1 \\
2.3 \\
2.3 .1 \\
2.1 .3 .1 \\
2.1 .3 .2 \\
2.1 .3 .3 \\
2.1 .3 .4 \\
2.1 .3 .5 \\
2.1 .3 .6 \\
2.3 .2 \\
2.3 .2 .1 \\
2.3 .2 .2 \\
2.3 .2 .3 \\
2.3 .2 .4 \\
2.3 .2 .5 \\
2.3 .2 .6\end{array}$} & Electric Motor (Cooling System and Support) \\
\hline & Instrumentation and Control \\
\hline & Process Heat Transport System \\
\hline & Process Heat He Transport System \\
\hline & Housing \\
\hline & Impeller \\
\hline & Motor \\
\hline & Magnetic Bearings \\
\hline & Rotor \\
\hline & Inverter \\
\hline & High Temperature Isolation Valve \\
\hline & Housing \\
\hline & Liner \\
\hline & Piston Cones \\
\hline & Valve Seats \\
\hline & Cone Positioning Struts \\
\hline & Insulation \\
\hline 3 & Hydrogen Production System (HPS) \\
\hline 3.1 & Undecided Hydrogen Production System \\
\hline 3.1 .1 & \\
\hline 3.1.1.1 & \\
\hline 3.1.2 & \\
\hline 3.1 .3 & \\
\hline 3.1.4 & \\
\hline 3.1 .5 & \\
\hline 3.2 & \\
\hline 3.2.1 & \\
\hline 3.2.2 & \\
\hline 3.3 & \\
\hline 3.3 .1 & \\
\hline 3.3.2 & \\
\hline 3.3 .3 & \\
\hline 3.3 .4 & \\
\hline 3.4 & HPS Control and Instrumentation System \\
\hline 3.5 & Feed and Utility Supply System \\
\hline 4 & Power Conversion System (PCS) \\
\hline
\end{tabular}

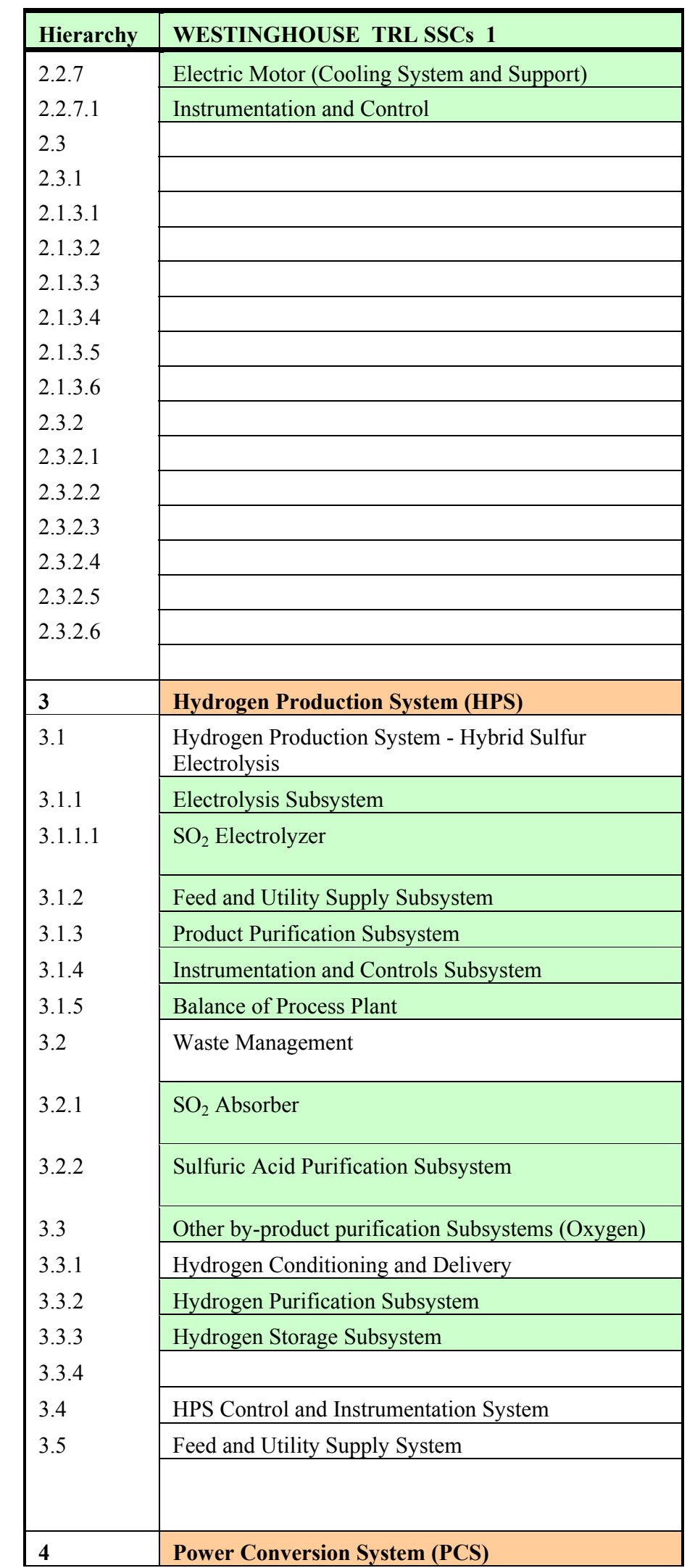

Power Conversion System (PCS)
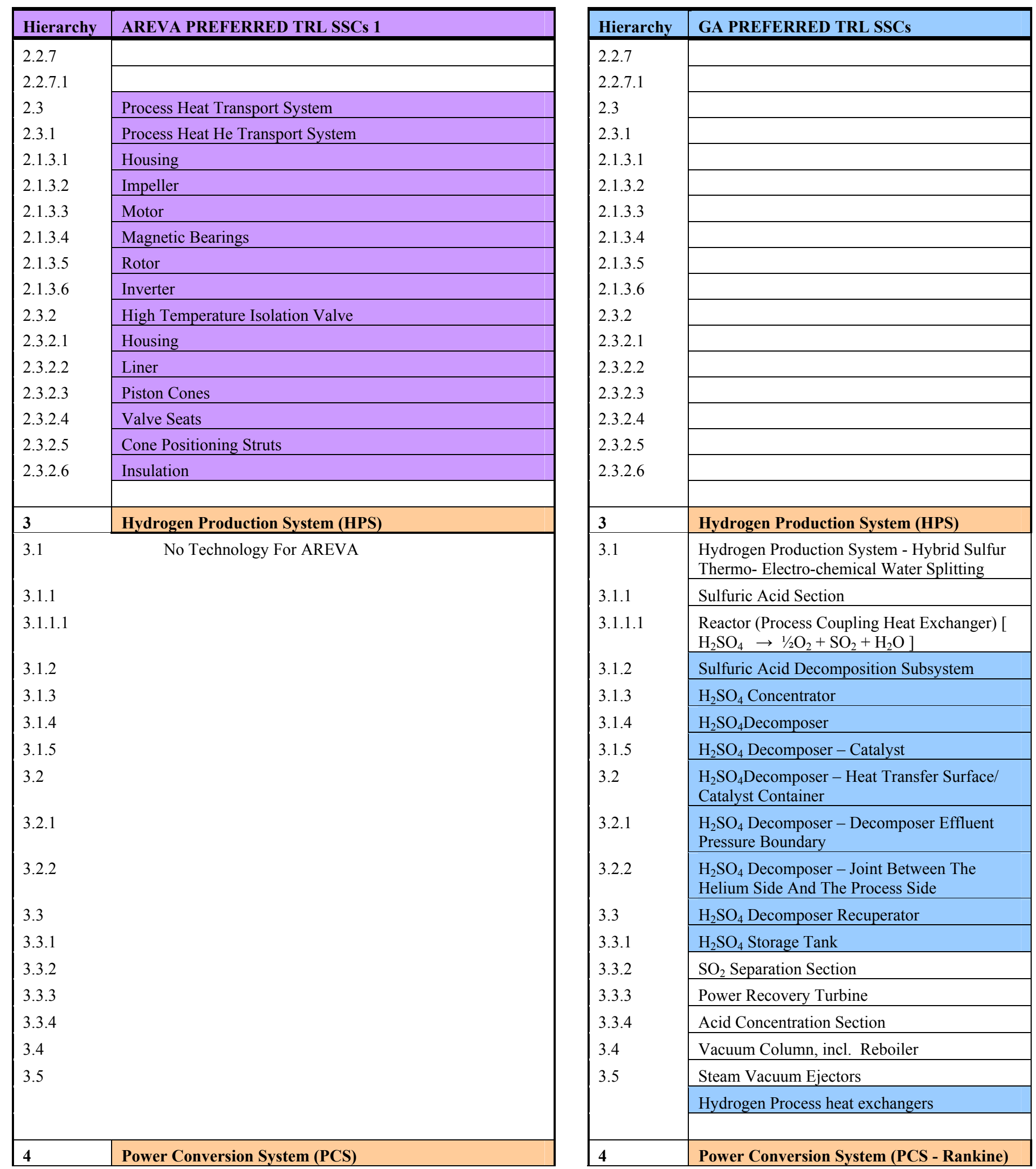


\begin{tabular}{|c|c|}
\hline Hierarchy & NGNP TRL MASTER COPY \\
\hline \multirow{2}{*}{$\begin{array}{l}4.1 \\
4.1 .1\end{array}$} & Turbine \\
\hline & Turbine Control Valve System \\
\hline 4.1 .2 & Compressor \\
\hline 4.1.3 & Intermediate Pressure Turbine \\
\hline 4.1.4 & $\begin{array}{l}\text { Generator and Auxiliaries (Including } \mathrm{H}_{2} \text { and } \\
\mathrm{CO}_{2} \text { ) }\end{array}$ \\
\hline 4.1 .5 & Low Pressure Turbine Units \\
\hline 4.1.6 & High Pressure Turbine \\
\hline 4.2 & $\begin{array}{l}\text { Interconnecting ducts, piping and other } \\
\text { Auxiliaries }\end{array}$ \\
\hline 4.3 & Shaft Configuration \\
\hline \multirow{2}{*}{$\begin{array}{l}4.3 .1 \\
4.3 .2\end{array}$} & Lube Oil System \\
\hline & Vacuum System \\
\hline 4.3 .3 & Air cooled Condenser \\
\hline \multirow{2}{*}{$\begin{array}{l}4.3 .3 .1 \\
4.3 .3 .2\end{array}$} & Fans \\
\hline & Deaerator \\
\hline 4.3.3.3 & A-frame \\
\hline \multirow{2}{*}{$\begin{array}{l}4.3 .3 .4 \\
4.4\end{array}$} & Piping \\
\hline & Main Steam System \\
\hline \multirow{2}{*}{$\begin{array}{l}4.4 .1 \\
4.4 .1 .1\end{array}$} & Steam Generator \\
\hline & Heat Recovery Steam Generator \\
\hline \multirow{2}{*}{$\begin{array}{l}4.4 .1 .2 \\
4.4 .1 .3\end{array}$} & Economizer \\
\hline & Boiler \\
\hline 4.4.1.4 & Reheater \\
\hline & Superheater \\
\hline & Outer Casing Insulation \\
\hline \multirow{2}{*}{$\begin{array}{l}4.4 .1 .7 \\
4.4 .1 .8\end{array}$} & Inner Surface Insulation \\
\hline & $\begin{array}{l}\text { Steam Generator Vessel Including External } \\
\text { Supports }\end{array}$ \\
\hline \multirow{2}{*}{$\begin{array}{l}4.4 .1 .9 \\
4.4 .1 .10\end{array}$} & Steam Generator Core \\
\hline & $\begin{array}{l}\text { Steam Generator Internal Ducts, Supports and } \\
\text { Insulation }\end{array}$ \\
\hline \multirow{2}{*}{$\begin{array}{l}\text { 4.4.1.11 } \\
4.4 .2\end{array}$} & SG Vessel Insulation \\
\hline & Condensate System \\
\hline 4.4.2.1 & Condenser \\
\hline \multirow{2}{*}{$\begin{array}{l}4.4 .2 .2 \\
4.4 .2 .3\end{array}$} & Condensate Water Pump \\
\hline & Vacuum Pump Unit \\
\hline \multirow{2}{*}{$\begin{array}{l}4.4 .3 \\
4.4 .4\end{array}$} & Feedwater Pump \\
\hline & Feedwater Heater \\
\hline & Steam Pipes \\
\hline & Isolation Valves \\
\hline \multirow{2}{*}{$\begin{array}{l}4.4 .7 \\
4.4 .8\end{array}$} & Valves \\
\hline & Startup/Shutdown Steam System \\
\hline \multirow{2}{*}{$\begin{array}{l}4.4 .9 \\
4.4 .10\end{array}$} & Extraction and Auxiliary Steam System \\
\hline & Steam Bypass/Dump System \\
\hline
\end{tabular}

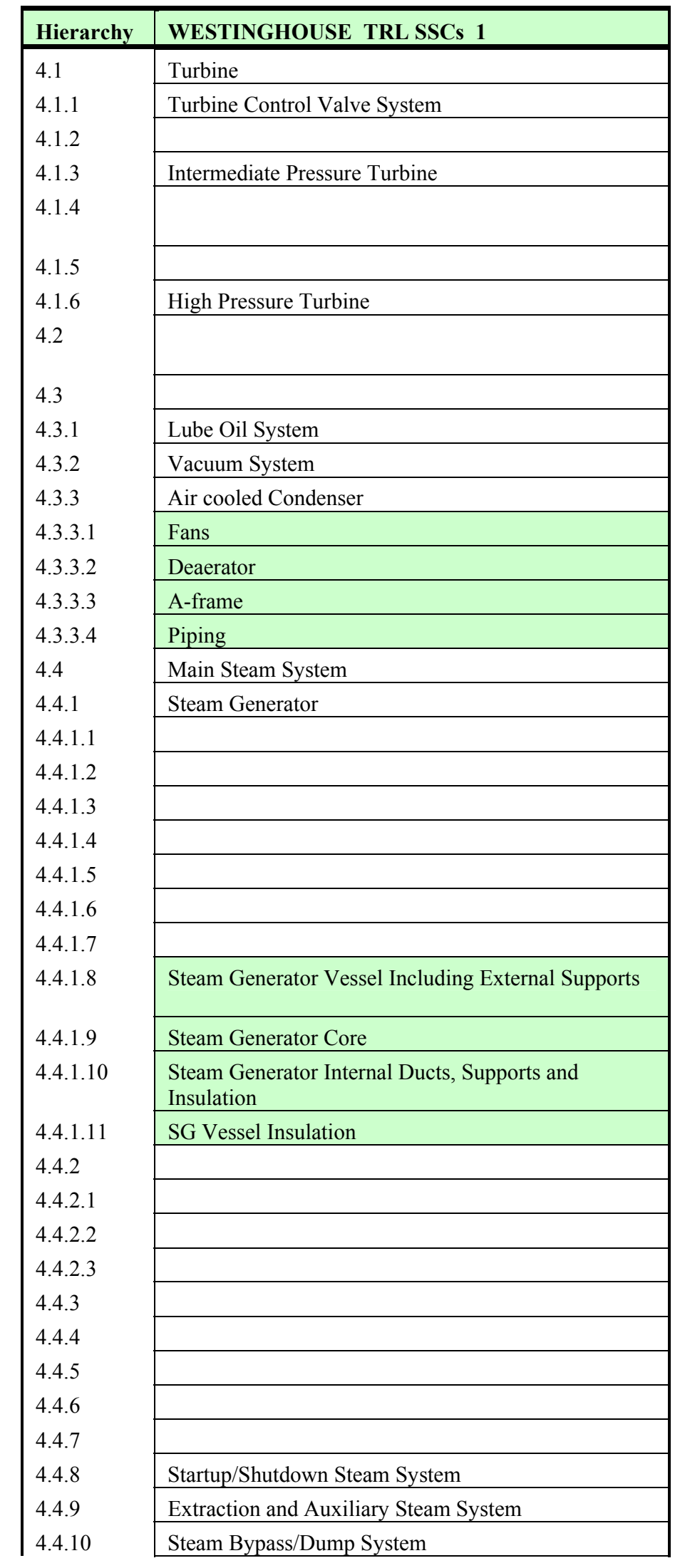

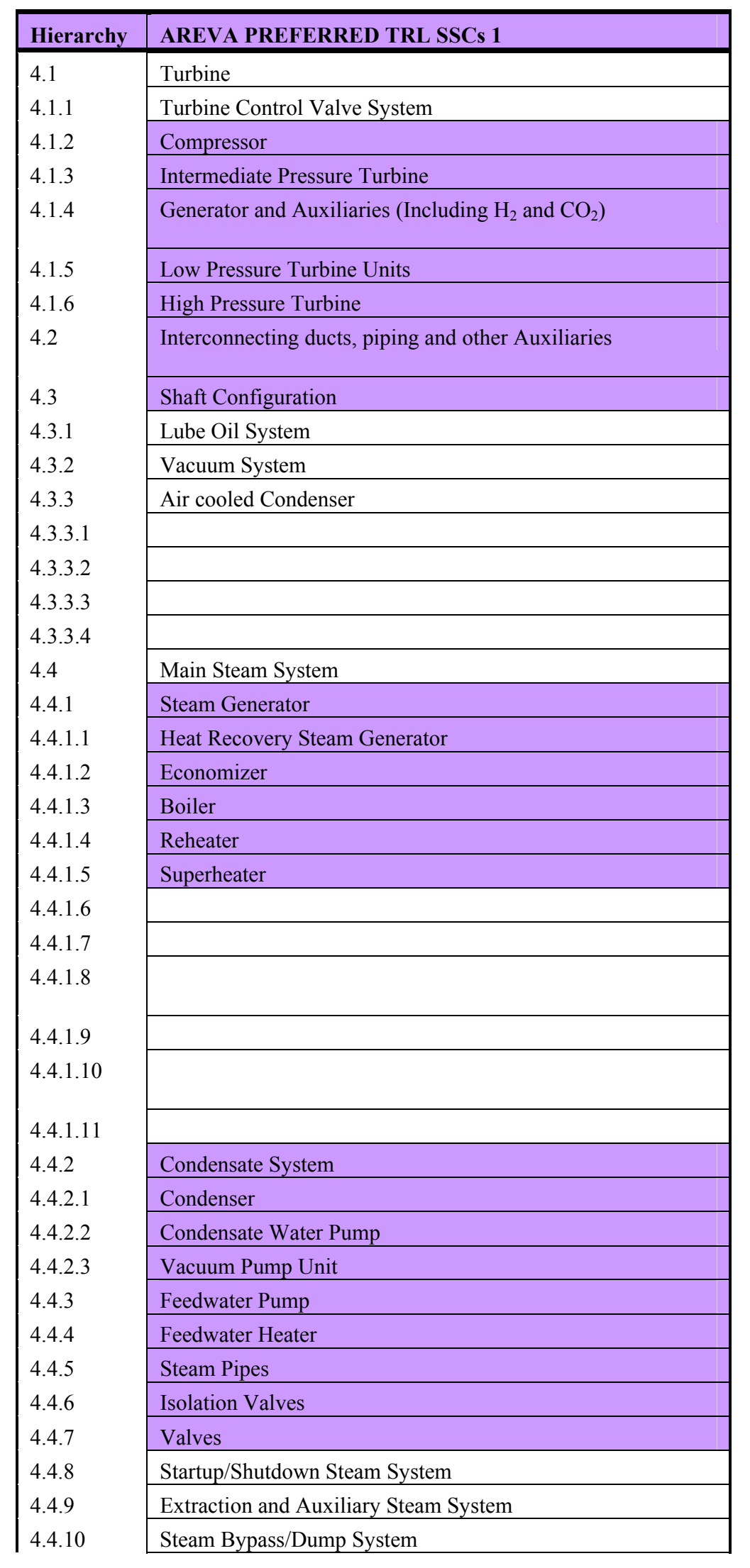




\begin{tabular}{|c|c|}
\hline Hierarchy & NGNP TRL MASTER COPY \\
\hline 4.4.11 & Seal Water System \\
\hline 4.4.12 & Gland Steam System \\
\hline 4.4.13 & Steam Vents and Drains \\
\hline 4.4.14 & Steam Pressure Relief System \\
\hline 4.5 & Feed Water and Condensate System \\
\hline 4.5.1 & Heater Drains System \\
\hline 4.5.2 & Feedwater Heater System \\
\hline 4.5.3 & High-Pressure Feedwater Pump \\
\hline 4.5 .4 & Condensate Pumps \\
\hline 4.6 & PCS Control and Instrumentations System \\
\hline 4.7 & Electricity Conditioning and Delivery \\
\hline 4.8 & PCS Water Supply and Treatment System \\
\hline 4.8.1 & Condensate Polishing System \\
\hline 4.8.2 & Turbine Plant Sampling System \\
\hline 4.8 .3 & Chemical Feed System \\
\hline 4.9 & PCS Component Cooling Water System \\
\hline 4.10 & Turbine Building HVAC \\
\hline 4.11 & Turbo Machinery \\
\hline 4.11 .1 & Turbo Machine \\
\hline 4.11 .2 & Turbine \\
\hline 4.11 .3 & LPC \\
\hline 4.11 .4 & HPC \\
\hline 4.11 .5 & TC Electro magnetic bearing System component \\
\hline 4.11 .6 & Seals/sliding seals, buffer and repair seals \\
\hline 4.11 .7 & Recuperator \\
\hline 4.11 .8 & Vertical Modules \\
\hline 4.11 .9 & $\begin{array}{l}\text { Pre-cooler \& Inter-cooler \& Generator Gas } \\
\text { Cooler Design }\end{array}$ \\
\hline 4.11 .10 & In-vessel metal work. \\
\hline 5 & Balance of Plant (BOP) Systems \\
\hline 5.1 & Plant Control and Instrumentation Systems \\
\hline 5.1 .1 & Central Control and Supervisory Subsystem \\
\hline 5.1 .2 & Radiation Monitoring Subsystem \\
\hline 5.1 .3 & Plant Communication Subsystem \\
\hline 5.1 .4 & Security System \\
\hline 5.1 .5 & Process Automation Subsystem \\
\hline 5.2 & Plant Electrical Distribution System \\
\hline 5.2 .1 & $\begin{array}{l}\begin{array}{l}\text { Medium Voltage Electrical Distribution } \\
\text { Subsystem }\end{array} \\
\text { S }\end{array}$ \\
\hline 5.2 .2 & High Voltage Electrical Distribution Subsystem \\
\hline 5.2 .3 & Standby AC Power Subsystem \\
\hline 5.2 .4 & $\begin{array}{l}\text { Rectifier / Power Conditioning for HPS } \\
\text { Electrolyzers }\end{array}$ \\
\hline
\end{tabular}

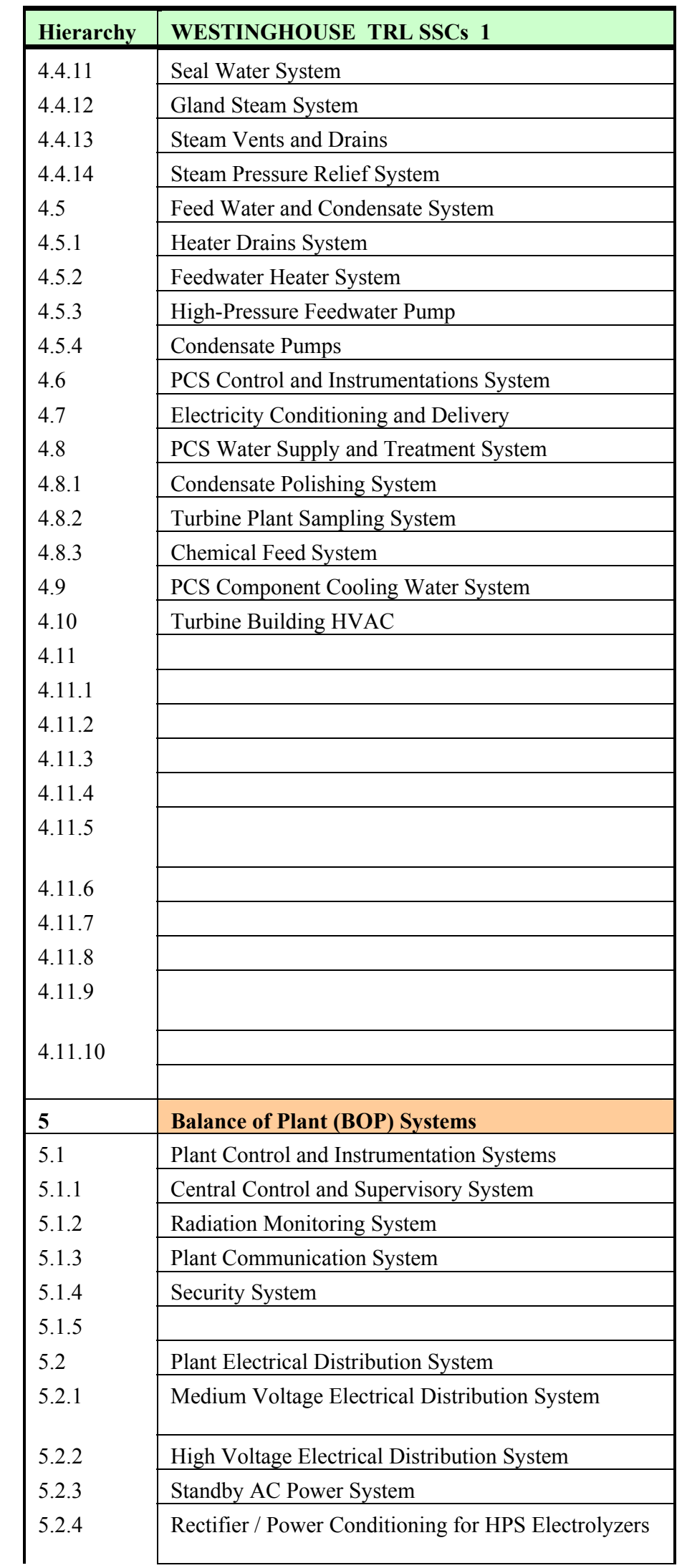

\begin{tabular}{|c|c|}
\hline Hierarchy & GA PREFERRED TRL SSCs \\
\hline 4.4.11 & Seal Water System \\
\hline 4.4.12 & Gland Steam System \\
\hline 4.4.13 & Steam Vents and Drains \\
\hline 4.4.14 & Steam Pressure Relief System \\
\hline 4.5 & Feed Water and Condensate System \\
\hline 4.5 .1 & Heater Drains System \\
\hline 4.5 .2 & Feedwater Heater System \\
\hline 4.5 .3 & High-Pressure Feedwater Pump \\
\hline 4.5 .4 & Condensate Pumps \\
\hline 4.6 & PCS Control and Instrumentations System \\
\hline 4.7 & Electricity Conditioning and Delivery \\
\hline 4.8 & PCS Water Supply and Treatment System \\
\hline 4.8.1 & Condensate Polishing System \\
\hline 4.8.2 & Turbine Plant Sampling System \\
\hline 4.8 .3 & Chemical Feed System \\
\hline 4.9 & PCS Component Cooling Water System \\
\hline 4.10 & Turbine Building HVAC \\
\hline 4.11 & Turbo Machinery \\
\hline 4.11 .1 & Turbo Machine \\
\hline 4.11 .2 & Turbine \\
\hline 4.11 .3 & LPC \\
\hline 4.11 .4 & HPC \\
\hline 4.11 .5 & $\begin{array}{l}\text { TC Electro magnetic bearing System } \\
\text { component }\end{array}$ \\
\hline 4.11 .6 & Seals/liding seals, buffer and repair seals \\
\hline 4.11 .7 & Recuperator \\
\hline 4.11 .8 & Vertical Modules \\
\hline 4.11 .9 & $\begin{array}{l}\text { Pre-cooler \& Inter-cooler \& Generator Gas } \\
\text { Cooler Design }\end{array}$ \\
\hline 4.11 .10 & In-vessel metal work. \\
\hline 5 & Balance of Plant (BOP) Systems \\
\hline 5.1 & Plant Control and Instrumentation Systems \\
\hline 5.1 .1 & Central Control and Supervisory System \\
\hline 5.1 .2 & Radiation Monitoring System \\
\hline 5.1 .3 & Plant Communication System \\
\hline 5.1 .4 & Security System \\
\hline 5.1 .5 & \\
\hline 5.2 & Plant Electrical Distribution System \\
\hline 5.2 .1 & $\begin{array}{l}\text { Medium Voltage Electrical Distribution } \\
\text { System }\end{array}$ \\
\hline 5.2 .2 & High Voltage Electrical Distribution System \\
\hline 5.2 .3 & Standby AC Power System \\
\hline 5.2 .4 & $\begin{array}{l}\text { Rectifier / Power Conditioning for HPS } \\
\text { Electrolyzers }\end{array}$ \\
\hline
\end{tabular}

Electrolyzer

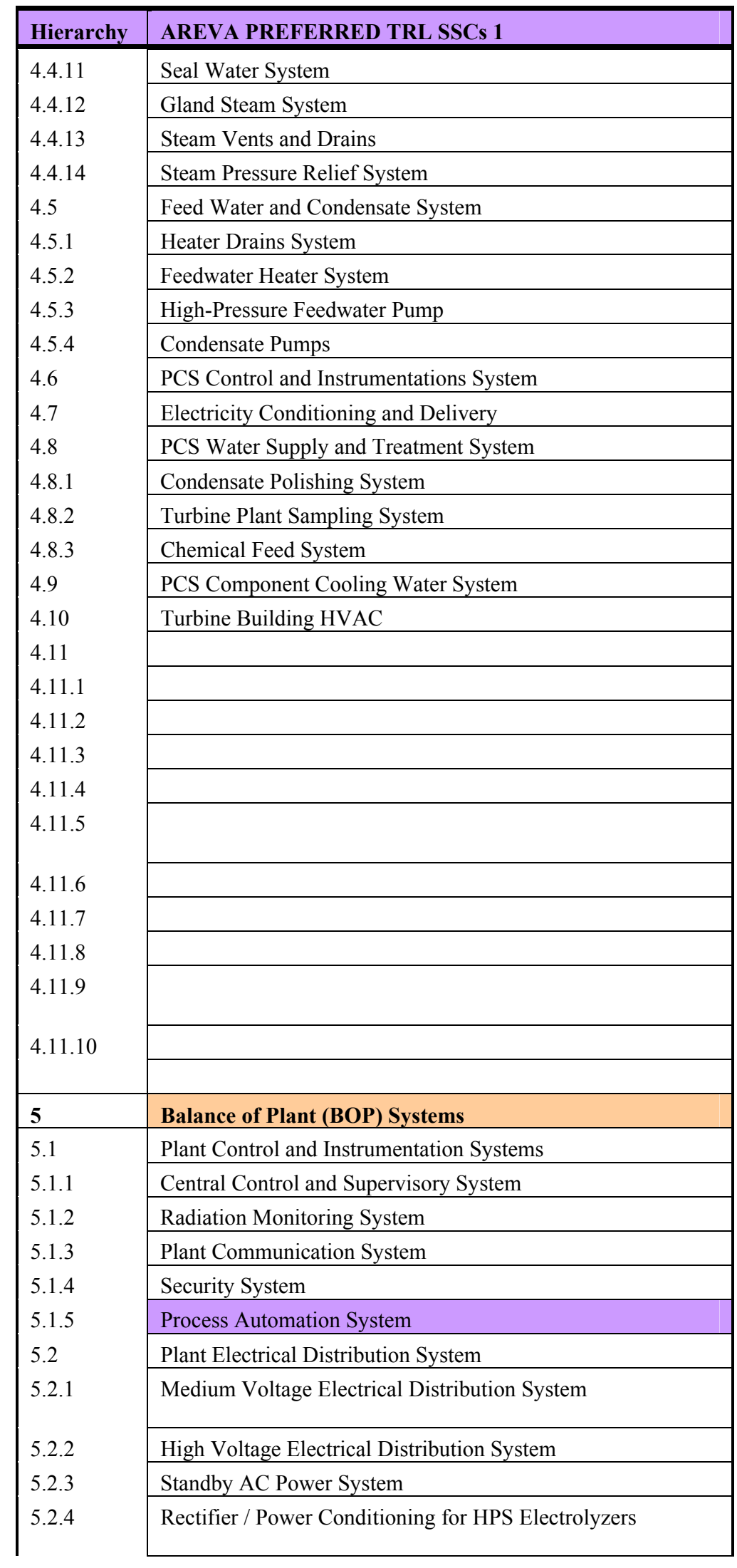




\begin{tabular}{|c|c|}
\hline Hierarchy & NGNP TRL MASTER COPY \\
\hline 5.3 & Plant Water System \\
\hline 5.4 & Auxiliary Cooling Water System \\
\hline 5.5 & Potable Water System \\
\hline 5.6 & Demineralized Water System \\
\hline 5.7 & Chilled Water System \\
\hline 5.8 & BOP HVAC System \\
\hline 5.9 & Compressed Air System \\
\hline 5.9 .1 & Instrument Air \\
\hline 5.9.2 & Service Air \\
\hline 5.9 .3 & Breathing Air \\
\hline 5.10 & Equipment Handling System \\
\hline 5.11 & Decontamination System \\
\hline 5.11 .1 & High Pressure Devices \\
\hline 5.11 .2 & Degreasing Unit \\
\hline 5.11 .3 & Ultrasonic Unit \\
\hline 5.12 & Waste Handling System \\
\hline 5.12 .1 & Solid and Condensed Waste Handling System \\
\hline 5.12 .2 & Liquid waste Handling System \\
\hline 5.12.2.1 & Clean Water Systems \\
\hline 5.12.2.2 & Dirty Water Systems \\
\hline 5.12 .3 & High Level Waste Handling Subsystem \\
\hline 5.12 .4 & Gaseous Radioactive Waste System \\
\hline 5.13 & Wastewater Treatment System \\
\hline 5.14 & Fire Protection System \\
\hline 5.15 & Environmental Monitoring System \\
\hline 5.15 .1 & Seismic Monitoring Subsystem \\
\hline 5.15 .2 & Meteorological Monitoring Subsystem \\
\hline 5.16 & Sanitary Sewer System \\
\hline 5.17 & Storm Water System \\
\hline 5.18 & Gas Storage System \\
\hline 5.19 & Auxiliary Boiler System \\
\hline 5.20 & Instrumentation \& Control (I\&C) \\
\hline 5.20 .1 & Safety Related Subsystems \\
\hline 5.20.1.1 & Reactor Protection System (RPS) \\
\hline 5.20.1.2 & Reactor Control and Limitation System (RCLS) \\
\hline 5.20 .1 .3 & Priority Actuator Control System (PACS) \\
\hline 5.20 .1 .4 & Post Accident Monitoring System (PAMS) \\
\hline 5.20.1.5 & Seismic Monitoring System (SeMS) \\
\hline 5.20.1.6 & Investment Protection System (IPS) \\
\hline 5.20 .1 .7 & Diagnostic and Maintenance System \\
\hline 5.20 .2 & Plant Monitoring System \\
\hline 5.20.2.1 & Process Information and Control System \\
\hline 5.20.2.2 & Safety Information and Control System \\
\hline 5.20 .2 .3 & Testing Phase Infrastructure \\
\hline
\end{tabular}

\begin{tabular}{|c|c|}
\hline Hierarchy & WESTINGHOUSE TRL SSCS 1 \\
\hline 5.3 & Plant Water System \\
\hline 5.4 & Auxiliary Cooling Water System \\
\hline 5.5 & Portable Water System \\
\hline 5.6 & Demineralized Water System \\
\hline 5.7 & Chilled Water System \\
\hline 5.8 & BOP HVAC System \\
\hline 5.9 & Compressed Air System \\
\hline 5.9 .1 & Instrument Air \\
\hline 5.9 .2 & Service Air \\
\hline 5.9 .3 & Breathing Air \\
\hline 5.10 & Equipment Handling System \\
\hline 5.11 & Decontamination System \\
\hline 5.11 .1 & \\
\hline 5.11 .2 & \\
\hline 5.11 .3 & \\
\hline 5.12 & Waste Handling System \\
\hline 5.12 .1 & Solid and Condensed Waste Handling System \\
\hline 5.12 .2 & Liquid waste Handling System \\
\hline 5.1.2.2.1 & Clean Water Systems \\
\hline 5.1.2.2.2. & Dirty Water Systems \\
\hline 5.12 .3 & High Level Waste Handling Subsystem \\
\hline 5.12 .4 & \\
\hline 5.13 & Wastewater Treatment System \\
\hline 5.14 & Fire Protection System \\
\hline 5.15 & Environmental Monitoring System \\
\hline 5.15 .1 & Seismic Monitoring System \\
\hline 5.15 .2 & Meteorological Monitoring System \\
\hline 5.16 & Sanitary Sewer System \\
\hline 5.17 & Storm Water System \\
\hline 5.18 & Gas Storage System \\
\hline 5.19 & Auxiliary Boiler System \\
\hline 5.20 & Instrumentation \& Control (I\&C) \\
\hline 5.20 .1 & Safety Related SubSystems \\
\hline 5.20.1.1 & \\
\hline 5.20 .1 .2 & \\
\hline 5.20 .1 .3 & \\
\hline 5.20.1.4 & \\
\hline 5.20 .1 .5 & \\
\hline 5.20 .1 .6 & \\
\hline $\begin{array}{l}5.20 .1 .7 \\
5.20 .2\end{array}$ & \\
\hline 5.20 .2 .1 & \\
\hline 5.20 .2 .2 & \\
\hline 5.20 .2 .3 & Testing Phase Infrastructure \\
\hline
\end{tabular}

\begin{tabular}{|c|c|}
\hline Hierarchy & AREVA PREFERRED TRL SSCs 1 \\
\hline 5.3 & Plant Water System \\
\hline 5.4 & Auxiliary Cooling Water System \\
\hline 5.5 & Portable Water System \\
\hline 5.6 & Demineralized Water System \\
\hline 5.7 & Chilled Water System \\
\hline 5.8 & BOP HVAC System \\
\hline 5.9 & Compressed Air System \\
\hline 5.9 .1 & Instrument Air \\
\hline 5.9 .2 & Service Air \\
\hline 5.9 .3 & Breathing Air \\
\hline 5.10 & Equipment Handling System \\
\hline 5.11 & Decontamination System \\
\hline 5.11 .1 & High Pressure Devices \\
\hline 5.11 .2 & Degreasing Unit \\
\hline 5.11 .3 & Ultrasonic Unit \\
\hline 5.12 & Waste Handling System \\
\hline 5.12 .1 & Solid Radioactive Waste System \\
\hline 5.12 .2 & Liquid Radioactive Waste System \\
\hline 5.1.2.2.1 & Clean Water Systems \\
\hline 5.1.2.2.2 & Dirty Water Systems \\
\hline 5.12 .3 & High Level Waste Handling Subsystem \\
\hline 5.12 .4 & Gaseous Radioactive Waste System \\
\hline 5.13 & Wastewater Treatment System \\
\hline 5.14 & Fire Protection System \\
\hline 5.15 & Environmental Monitoring System \\
\hline 5.15 .1 & Seismic Monitoring System \\
\hline 5.15 .2 & Meteorological Monitoring System \\
\hline 5.16 & Sanitary Sewer System \\
\hline 5.17 & Storm Water System \\
\hline 5.18 & Gas Storage System \\
\hline 5.19 & Auxiliary Boiler System \\
\hline 5.20 & Instrumentation \& Control $(\mathrm{I} \& \mathrm{C})$ \\
\hline 5.20 .1 & Safety Related Subsystems \\
\hline 5.20.1.1 & Reactor Protection System (RPS) \\
\hline 5.20 .1 .2 & Reactor Control and Limitation System (RCLS) \\
\hline 5.20 .1 .3 & Priority Actuator Control System (PACS) \\
\hline 5.20.1.4 & Post Accident Monitoring System (PAMS) \\
\hline 5.20 .1 .5 & Seismic Monitoring System (SeMS) \\
\hline 5.20 .1 .6 & Investment Protection System (IPS) \\
\hline 5.20 .1 .7 & Diagnostic and Maintenance System \\
\hline 5.20 .2 & Plant Monitoring System \\
\hline 5.20 .2 .1 & Process Information and Control System \\
\hline 5.20 .2 .2 & Safety Information and Control System \\
\hline 5.20 .2 .3 & Testing Phase Infrastructure \\
\hline
\end{tabular}

\begin{tabular}{|c|c|}
\hline Hierarchy & GA PREFERRED TRL SSCs \\
\hline 5.3 & Plant Water System \\
\hline 5.4 & Auxiliary Cooling Water System \\
\hline 5.5 & Portable Water System \\
\hline 5.6 & Demineralized Water System \\
\hline 5.7 & Chilled Water System \\
\hline 5.8 & BOP HVAC System \\
\hline 5.9 & Compressed Air System \\
\hline 5.9 .1 & Instrument Air \\
\hline 5.9 .2 & Service Air \\
\hline 5.9 .3 & Breathing Air \\
\hline 5.10 & Equipment Handling System \\
\hline 5.11 & Decontamination System \\
\hline 5.11 .1 & \\
\hline $\begin{array}{l}5.11 .2 \\
51.2\end{array}$ & \\
\hline $\begin{array}{l}5.11 .3 \\
5.12\end{array}$ & Waste Handling System \\
\hline 5.12 .1 & Solid and Condensed Waste Handling System \\
\hline 5.12 .2 & Liquid waste Handling System \\
\hline 5.1.2.2.1 & Clean Water Systems \\
\hline 5.1.2.2.2. & Dirty Water Systems \\
\hline 5.12 .3 & High Level Waste Handling Subsystem \\
\hline 5.12 .4 & \\
\hline 5.13 & Wastewater Treatment System \\
\hline 5.14 & Fire Protection System \\
\hline 5.15 & Environmental Monitoring System \\
\hline 5.15 .1 & Seismic Monitoring System \\
\hline 5.15 .2 & Meteorological Monitoring System \\
\hline 5.16 & Sanitary Sewer System \\
\hline 5.17 & Storm Water System \\
\hline 5.18 & Gas Storage System \\
\hline 5.19 & Auxiliary Boiler System \\
\hline 5.20 & Instrumentation \& Control System (I\&C) \\
\hline 5.20 .1 & Safety Related Subsystems \\
\hline 5.20.1.1 & \\
\hline 5.20 .1 .2 & \\
\hline 5.20.1.3 & \\
\hline 5.20 .1 .4 & \\
\hline 5.20 .1 .5 & \\
\hline 5.20 .1 .6 & \\
\hline $\begin{array}{l}5.20 .1 .7 \\
5.20 .2\end{array}$ & \\
\hline 5.20 .2 .1 & \\
\hline 5.20 .2 .2 & \\
\hline 5.20 .2 .3 & Testing Phase Infrastructure \\
\hline
\end{tabular}




\begin{tabular}{|l|l|}
\hline Hierarchy & NGNP TRL MASTER COPY \\
\hline 5.20 .2 .4 & IT (Enterprise \& Infrastructure) \\
\cline { 2 - 2 } 5.21 & IT Systems \\
\cline { 2 - 2 } 5.21 .1 & Other \\
\cline { 2 - 2 } 5.22 & Instrumentation \\
5.22 .1 & Primary Loop Instrumentation ( Bounding Case) \\
5.22 .1 .1 & Flow Rate Measurement subsystem \\
5.22 .1 .2 & Reactor Cold Leg Temperature Sensors \\
\hline 5.22 .1 .3 & Reactor Hot Leg Temperature Sensors \\
\hline 5.22 .1 .4 & Moisture Sensors \\
\cline { 2 - 2 } 5.22 .1 .5 & Pressure Sensors \\
\hline
\end{tabular}

\begin{tabular}{|l|l|}
\hline Hierarchy & WESTINGHOUSE TRL SSCs 1 \\
\hline 5.20 .2 .4 & IT (Enterprise \& Infrastructure) \\
\cline { 2 - 2 } 5.21 & IT Systems \\
\cline { 2 - 2 } 5.21 .1 & Other \\
\cline { 2 - 2 } 5.22 & \\
\cline { 2 - 2 } 5.22 .1 & \\
\cline { 2 - 2 } 5.22 .1 .1 & \\
\cline { 2 - 2 } 5.22 .1 .2 & Sensors \\
\hline 5.22 .1 .3 & \\
\cline { 2 - 2 } 5.22 .1 .4 & \\
\cline { 2 - 2 } 5.22 .1 .5 & \\
\hline
\end{tabular}

\begin{tabular}{|l|l|}
\hline Hierarchy & AREVA PREFERRED TRL SSCs 1 \\
\hline 5.20 .2 .4 & IT (Enterprise \& Infrastructure) \\
\cline { 2 - 2 } 5.21 & IT Systems \\
\cline { 2 - 2 } 5.21 .1 & Other \\
\cline { 2 - 2 } 5.22 & Instrumentation \\
5.22.1 & Primary Loop Instrumentation ( Bounding Case) \\
5.22.1.1 & Flow Rate Measurement subsystem \\
\hline 5.22 .1 .2 & Reactor Cold Leg Temperature Sensors \\
5.22.1.3 & Reactor Hot Leg Temperature Sensors \\
5.22 .1 .4 & Moisture Sensors \\
\cline { 2 - 2 } 5.22 .1 .5 & Pressure Sensors \\
\hline
\end{tabular}

\begin{tabular}{|c|c|}
\hline Hierarchy & GA PREFERRED TRL SSCs \\
\hline \multirow{10}{*}{$\begin{array}{l}5.20 .2 .4 \\
5.21 \\
5.21 .1 \\
5.22 \\
5.22 .1 \\
5.22 .1 .1 \\
5.22 .1 .2 \\
5.22 .1 .3 \\
5.22 .1 .4 \\
5.22 .15\end{array}$} & IT (Enterprise \& Infrastructure) \\
\hline & IT Systems \\
\hline & Other \\
\hline & \\
\hline & \\
\hline & \\
\hline & \\
\hline & \\
\hline & \\
\hline & \\
\hline
\end{tabular}

AREVA SSCs

WEC SSCs

GA SSCs

\begin{tabular}{l}
\hline INL SSCs \\
\hline
\end{tabular} 


\section{Appendix B}

\section{Example NGNP Technology Development Roadmaps}




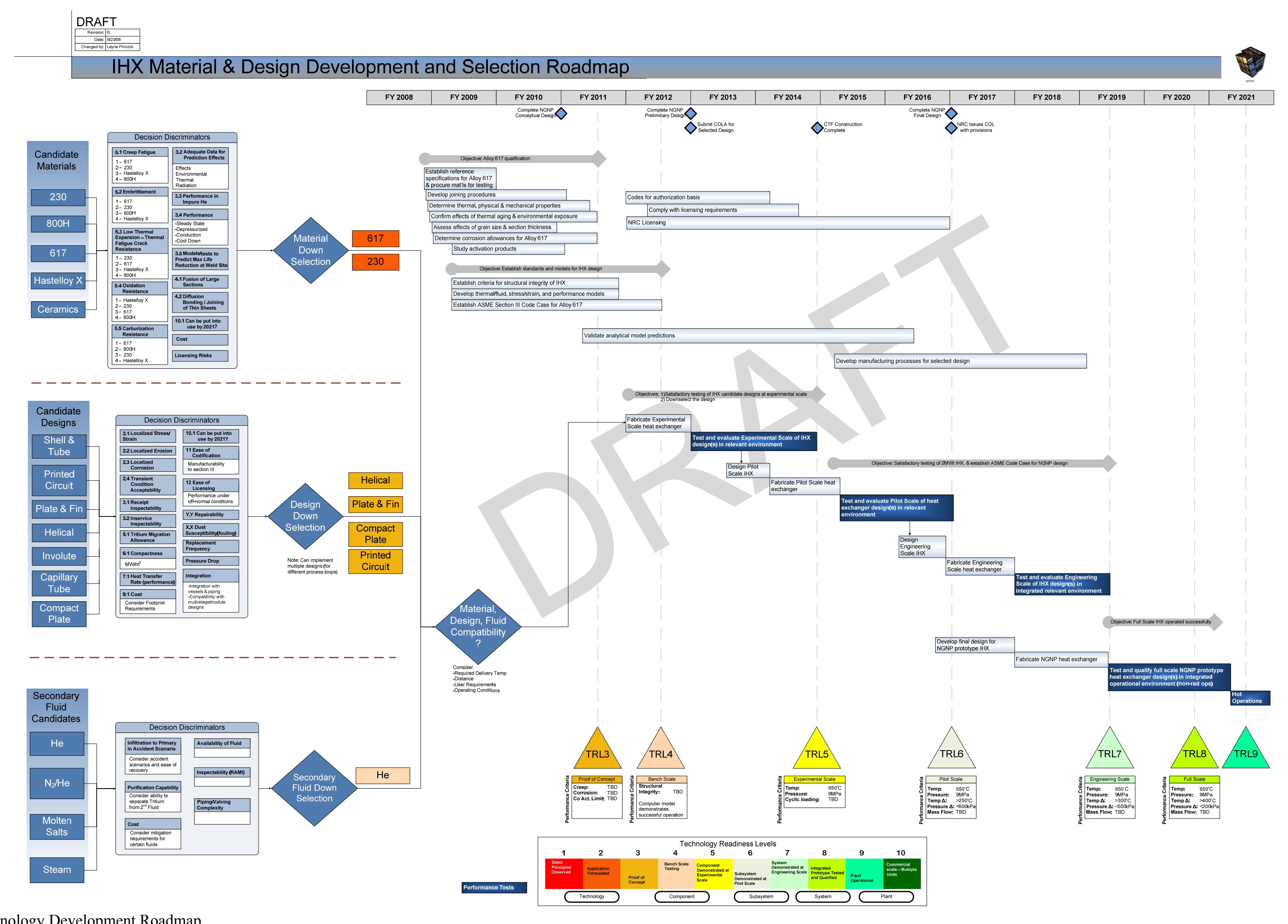




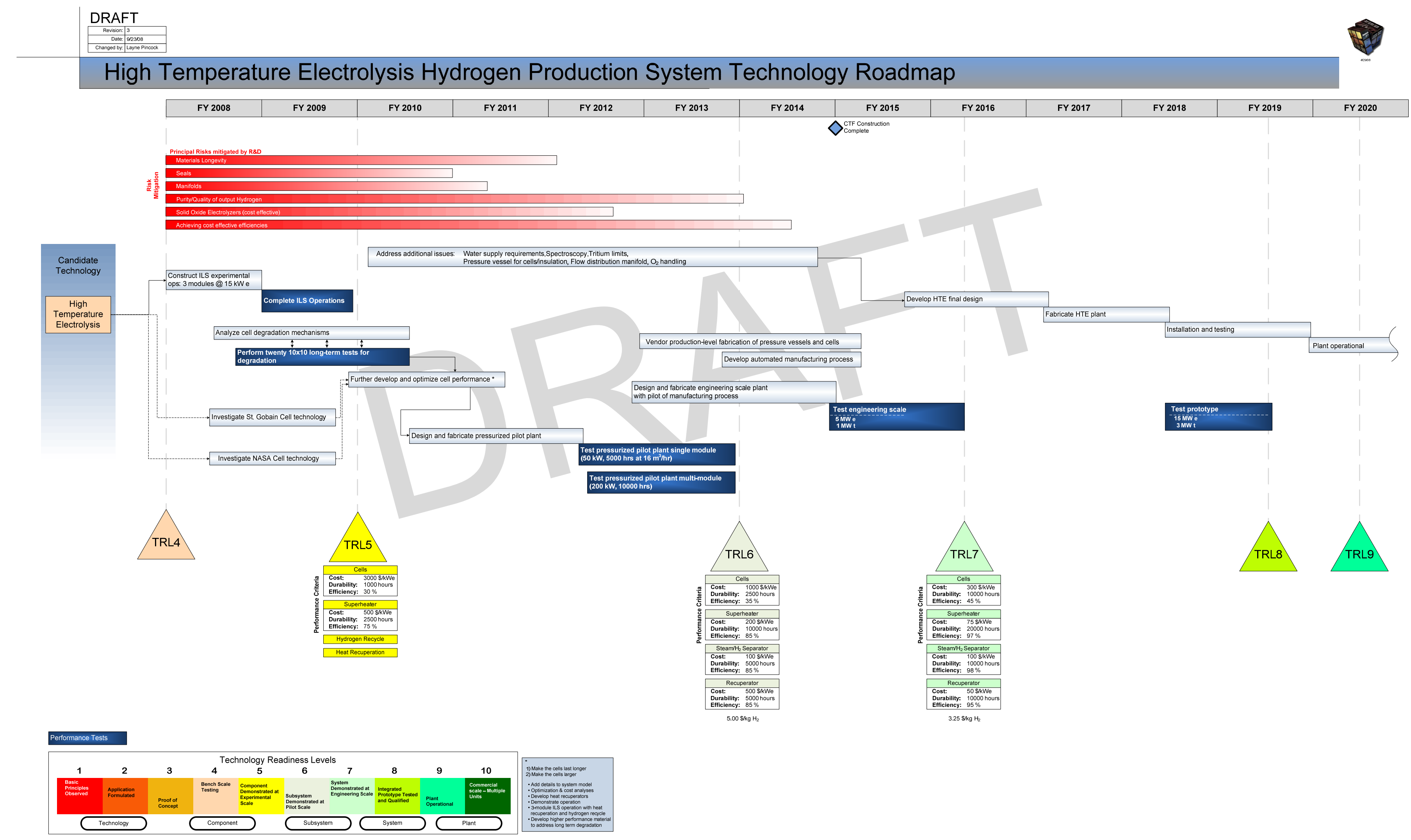

Figure B-2. HTE Hydrogen Production Technology Development Roadmap 


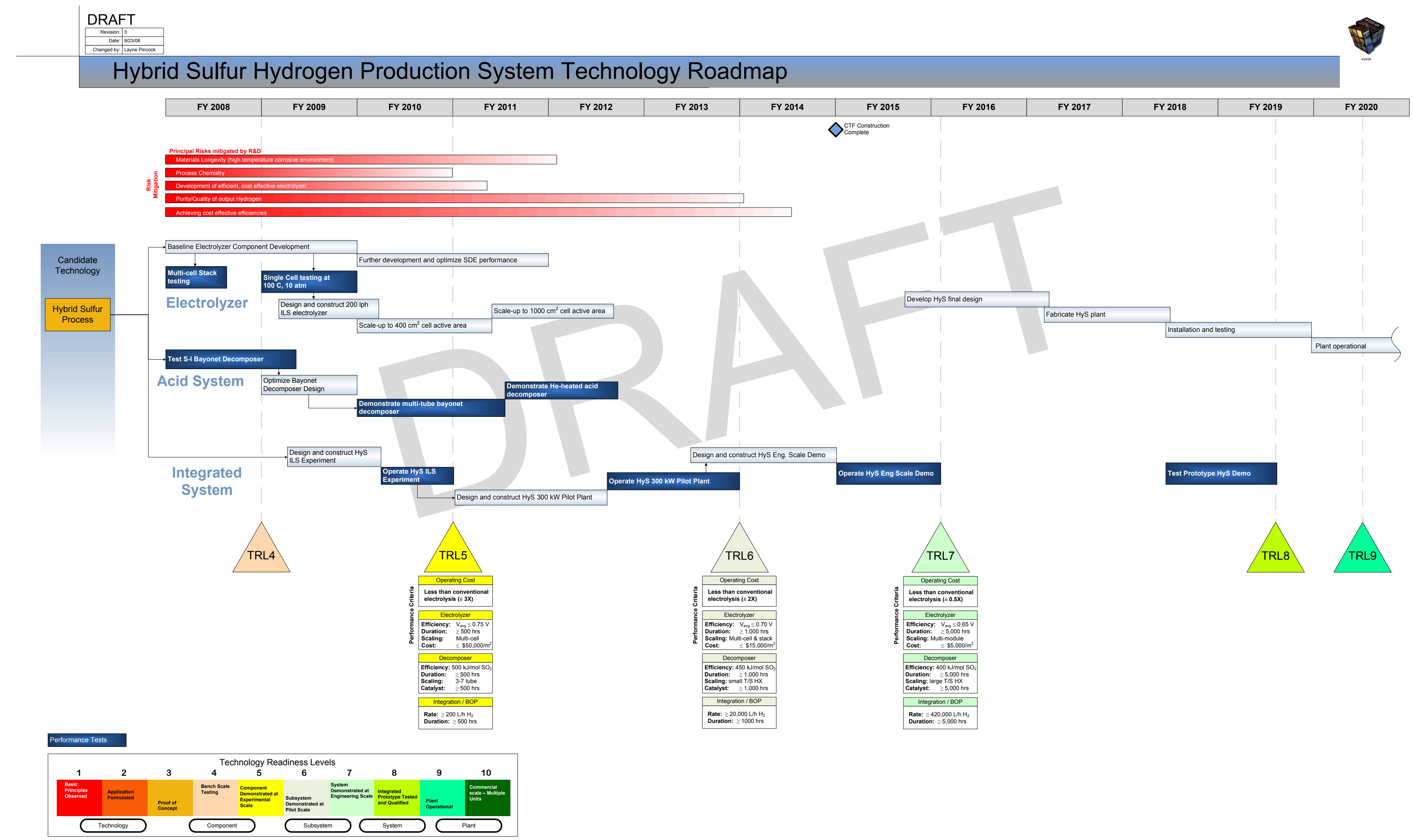

Figure B-3. Hybrid Sulfur Hydrogen Production Technology Development Roadmap 

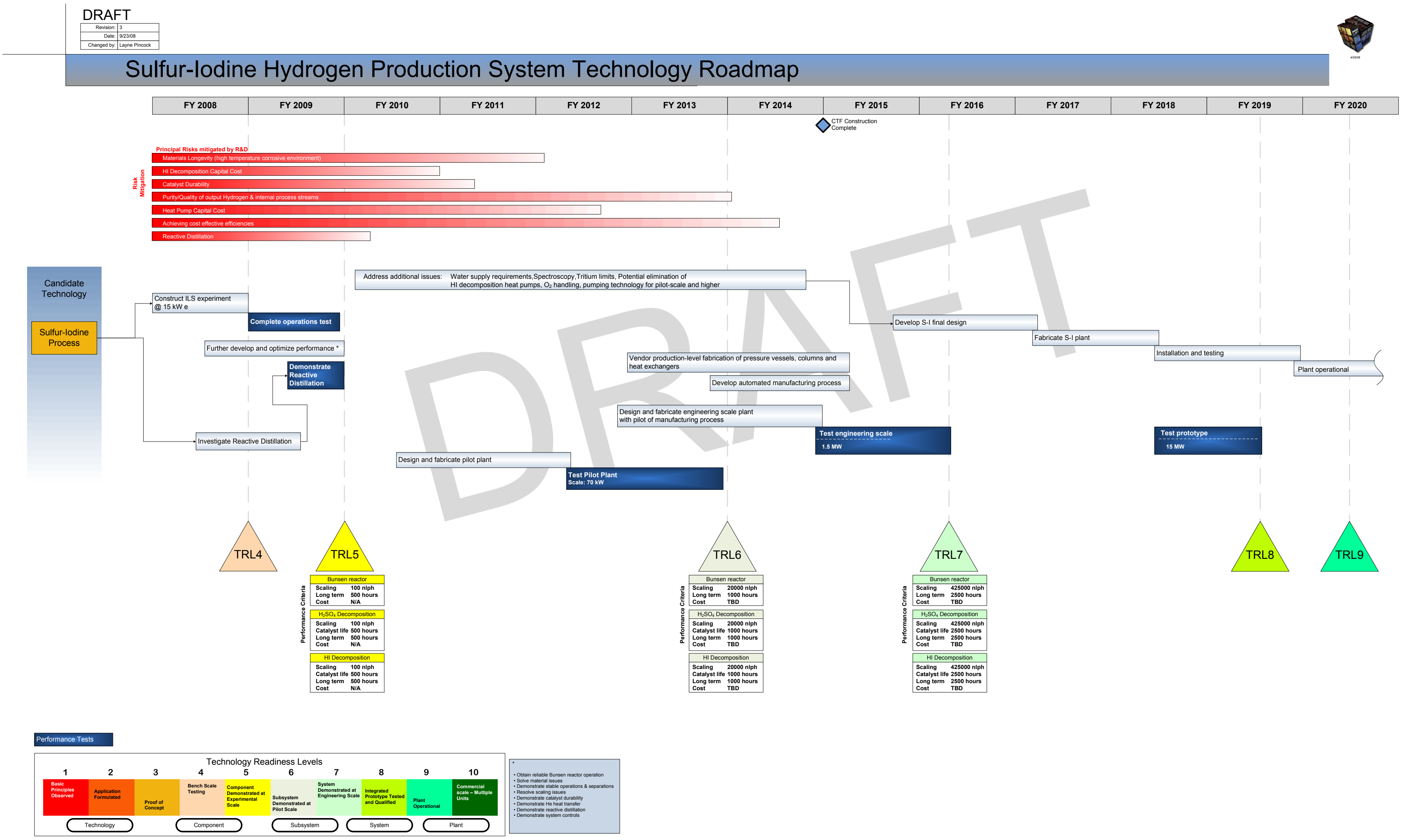

Figure B-4. Sulfur-Iodine Hydrogen Production Technology Development Roadmap 